\title{
Computational Assessment of Gaseous Reacting Flows in Single Element Injector
}

\author{
Emre Sozer ${ }^{*}$ \\ University of Michigan, Ann Arbor, MI \\ Aravind Vaidyanathan ${ }^{\dagger}$ \\ Iowa State University, Ames, IA \\ Corin Segal ${ }^{\ddagger}$ \\ University of Florida, Gainesville, FL \\ and \\ Wei Shyy ${ }^{\S}$ \\ University of Michigan, Ann Arbor, MI
}

\begin{abstract}
The injector flow is challenging to predict due to the complex physics involving recirculation, turbulence, mixing between multiple species and chemical reactions. This work is aimed at assessing the capability of a RANS-based computational modeling tool for gaseous injector flows. Both combustion effectiveness and chamber wall heat transfer profiles are examined to shed light on issues most pertinent to injector design. Two injector flow experiments by different researchers have been adopted to facilitate a direct comparison of the wall heat transfer data. For mixingdominated cases studied in these experiments, without detailed account for turbulence-chemistry interactions, particular choice of the chemical kinetics scheme is shown to be of minor importance. The near wall treatment of the turbulence model can noticeably impact the outcome of the simulation. While the results reported by various researchers for the same experiment vary noticeably, it seems that refinements of turbulence-chemistry interactions and the near wall treatment are needed.
\end{abstract}

$\begin{array}{ll}C V & =\text { control volume } \\ C S & =\text { control surface } \\ E & =\text { total specific energy of the mixture } \\ F_{i} & =\text { inviscid flux vector } \\ F_{v} & =\text { viscous flux vector } \\ h_{s} & =\text { species specific enthalpy } \\ k & =\text { turbulent specific kinetic energy } \\ k_{b} & =\text { backward reaction rate } \\ k_{f} & =\text { forward reaction rate } \\ K_{e} & =\text { equilibrium constant } \\ M_{S} & =\text { species molecular weight } \\ \boldsymbol{n} & =\text { surface normal }\end{array}$

\section{Nomenclature}

* Graduate Student Research Assistant, Aerospace Engineering Department

${ }^{\dagger}$ Postdoctoral Research Associate, Department of Mechanical Engineering

* Associate Professor, Mechanical and Aerospace Engineering Department

${ }^{\S}$ Clarence L. "Kelly" Johnson Collegiate Professor and Chair, Aerospace Engineering Department 


$\begin{array}{ll}p & =\text { pressure } \\ \boldsymbol{q} & =\text { heat conduction vector } \\ Q & =\text { conservative variable vector } \\ T & =\text { temperature } \\ \boldsymbol{u} & =\text { mean mixture velocity } \\ \mathbf{V}_{D s} & =\text { species diffusion velocity } \\ \dot{W} & =\text { species source vector } \\ \Phi & =\text { equivalence ratio } \\ \mu_{t} & =\text { dynamic eddy viscosity } \\ v_{t} & =\text { kinematic eddy viscosity } \\ v_{s, r}^{\prime} & =\text { reactant species stoichiometric coefficient } \\ v_{s, r}^{\prime \prime} & =\text { product species stoichiometric coefficient } \\ \omega & =\text { turbulent specific dissipation rate } \\ \Omega & =\text { absolute vorticity } \\ \rho_{s} & =\text { species density } \\ \rho & =\text { mixture density } \\ \boldsymbol{\tau} & =\text { stress tensor }\end{array}$

\section{Introduction}

One of the major challenges facing liquid rockets is the harsh thermal environment in the combustion chamber. A major goal of the liquid rocket injector design is to minimize the combustion length, i.e., faster mixing and burning of fuel and oxidizer. However, the extent to which the combustion length can be reduced is limited by increased local heat flux to the chamber wall resulting in possible material burn-out and crack. Various injector design approaches provide compromises between these two competing objectives. Before one can satisfactorily handle competing goals, adequate tools capable of predicting the reacting flow field and thermal environment under the injector operating conditions need to be available. To date, significant issues related to the computational fluid dynamics (CFD) analysis of such flows exist. There is a community-wide effort toward developing, evaluating, and refining CFD tools for this type of problems. This paper summarizes our efforts in assessing the performance of representative computational modeling tools for injector flow simulations.

Commonly, a liquid rocket injector consists of multiple injector elements arranged in patterned formation. While the arrangement of individual injector elements and their interactions play an important role in flow field characteristics, $\mathrm{GO}_{2} / \mathrm{GH}_{2}$ or $\mathrm{LOX} / \mathrm{GH}_{2}$ single shear co-axial injector problem attracted interest among both experimental and computational studies because it is simpler and it exhibits fluid physics similar to multiple element injectors. Even for a single-element configuration, the problem is still very challenging.

Table 1 summarizes selected studies based on computational modeling of single element $\mathrm{O}_{2} / \mathrm{H}_{2}$ shear coaxial injector flows. Here, we focus on two different experimental test cases by Vaidyanathan et al. ${ }^{23}$ and Pal et al. ${ }^{22}$ in our effort to examine the effects of grid resolution, choice of the chemistry mechanism, and the near wall treatments for velocity and temperature fields.

Table 1 Select literature on CFD simulations of $\mathrm{O}_{2} / \mathrm{H}_{2}$ shear coaxial injectors.

\begin{tabular}{|c|c|c|c|c|c|c|c|}
\hline Publication & Propellants & Test Case & $\begin{array}{c}\text { Pressure } \\
\text { (MPa) }\end{array}$ & Domain & $\begin{array}{l}\text { CFD } \\
\text { Code }\end{array}$ & $\begin{array}{c}\text { Turbulence } \\
\text { Model }\end{array}$ & $\begin{array}{c}\text { Chemistry } \\
\text { Model }\end{array}$ \\
\hline Foust et al. ${ }^{1}$ & $\mathrm{GO}_{2} / \mathrm{GH}_{2}$ & $\begin{array}{c}\text { Self } \\
\text { Measurement }\end{array}$ & 1.29 & $2 \mathrm{D}$ & $\mathrm{PSU}^{2}$ & $k-\varepsilon$ & $\begin{array}{l}\text { Finite-rate } \\
8 \text { species, } \\
18 \text { reactions }\end{array}$ \\
\hline Schley et al. ${ }^{3}$ & $\mathrm{GO}_{2} / \mathrm{GH}_{2}$ & Foust et al. ${ }^{1}$ & 1.29 & $2 \mathrm{D}$ & $\begin{array}{c}\mathrm{AS} \mathrm{D}^{4} \\
\mathrm{FDNS}^{5} \\
\mathrm{PSU}^{2}\end{array}$ & $k-\varepsilon$ & Finite-rate \\
\hline Oefelein et al. ${ }^{6}$ & $\mathrm{LOX} / \mathrm{GH}_{2}$ & Mayer et al. ${ }^{7}$ & 10.1 & $2 \mathrm{D}$ & $\mathrm{PSU}^{2}$ & LES & $\begin{array}{l}\text { Finite-rate } \\
9 \text { species, } \\
24 \text { reactions }\end{array}$ \\
\hline Ivancic et al. ${ }^{8}$ & $\mathrm{LOX} / \mathrm{GH}_{2}$ & $\begin{array}{c}\text { Self } \\
\text { Measurement }\end{array}$ & 6 & $2 \mathrm{D}$ & $\mathrm{AS} \mathrm{D}^{4}$ & $k-\varepsilon$ & Equilibrium \\
\hline
\end{tabular}

American Institute of Aeronautics and Astronautics 


\begin{tabular}{|c|c|c|c|c|c|c|c|}
\hline Lin et al. ${ }^{9}$ & $\mathrm{GO}_{2} / \mathrm{GH}_{2}$ & Marshall et al. ${ }^{10}$ & 5.2 & $2 \mathrm{D}$ & $\begin{array}{c}\text { FDNS }^{5} \\
\text { Loci-Chem }^{11,12}\end{array}$ & $\begin{array}{l}\text { Menter's } \\
\text { Baseline }\end{array}$ & $\begin{array}{l}\text { Finite-rate } \\
7 \text { species, } \\
9 \text { reactions }\end{array}$ \\
\hline Oefelein ${ }^{13}$ & $\mathrm{LOX} / \mathrm{GH}_{2}$ & Oschwald et al. ${ }^{14}$ & 10.1 & $3 \mathrm{D}$ & & $\begin{array}{l}\text { DNS } \\
\text { LES }\end{array}$ & $\begin{array}{l}\text { Finite-rate } \\
9 \text { species, } \\
19 \text { reactions }\end{array}$ \\
\hline heng et al. ${ }^{15}$ & $\mathrm{LOX} / \mathrm{GH}_{2}$ & $\begin{array}{l}\text { Vingert et al. } .^{16} \\
\text { Thomas et al. }{ }^{17}\end{array}$ & $\begin{array}{l}1 \\
6\end{array}$ & $2 \mathrm{D}$ & FDNS $^{5}$ & $k-\varepsilon$ & $\begin{array}{l}\text { Finite-rate } \\
6 \text { species } \\
9 \text { reactions }\end{array}$ \\
\hline Mack et al. ${ }^{18}$ & $\mathrm{GO}_{2} / \mathrm{GH}_{2}$ & Conley et al. ${ }^{19}$ & 2.75 & $3 \mathrm{D}$ & Loci-Stream $^{11,20}$ & $\begin{array}{l}\text { Menter's } \\
\text { Baseline }\end{array}$ & $\begin{array}{c}\text { Finite-rate } \\
6 \text { species } \\
9 \text { reactions }\end{array}$ \\
\hline ucker et al. ${ }^{21}$ & $\mathrm{GO}_{2} / \mathrm{GH}_{2}$ & Pal et al. ${ }^{22}$ & 5.42 & $\begin{array}{l}3 \mathrm{D} \\
3 \mathrm{D} \\
2 \mathrm{D} \\
2 \mathrm{D} \\
2 \mathrm{D}\end{array}$ & $\begin{array}{c}- \\
\text { LESLIE3D } \\
- \\
\text { GEMS } \\
\text { Loci-Chem }^{11,12}\end{array}$ & $\begin{array}{l}\text { LES } \\
\text { LES } \\
\text { LES } \\
\text { URANS } \\
\text { RANS }\end{array}$ & $\begin{array}{c}\text { Finite-rate } \\
\text { Finite-rate } \\
\text { Flamelet } \\
\text { Finite-rate } \\
\text { Finite-rate }\end{array}$ \\
\hline
\end{tabular}

\section{Governing Equations and Computational Modeling Approaches}

A density-based, finite volume code, Loci-Chem ${ }^{11,12}$, is utilized in this study. The code is capable of handling mixed element type unstructured grids. The convective fluxes are based on Roe's flux difference splitting ${ }^{24}$. Both convective and diffusive fluxes are evaluated to second order accuracy. Shear Stress Transport ${ }^{25}$ (SST) model as described below is used for turbulence closure. Steady state solution is achieved by marching in time with a local time stepping procedure.

For a control volume $C V$ bounded by the control surface $C S$, Navier Stokes equations with non-equilibrium chemistry can be written as:

$$
\begin{gathered}
\frac{d}{d t} \int_{C V} Q d V+\int_{C S}\left(F_{i}-F_{v}\right) d S=\int_{C V} \dot{W} d V \\
Q=\left[\begin{array}{c}
\rho_{1} \\
\vdots \\
\rho_{S} \\
\vdots \\
\rho \\
\rho \mathbf{u} \\
\rho E
\end{array}\right], \quad F_{i}=\left[\begin{array}{c}
\rho_{1} \mathbf{u} \cdot \mathbf{n} \\
\vdots \\
\rho_{s} \mathbf{u} \cdot \mathbf{n} \\
\vdots \\
\rho \mathbf{u} \cdot \mathbf{n} \\
\rho \mathbf{u}(\mathbf{u} \cdot \mathbf{n})+p \mathbf{I} \cdot \mathbf{n} \\
(\rho E+p) \mathbf{u} \cdot \mathbf{n}
\end{array}\right], \quad F_{v}=\left[\begin{array}{c}
-\rho_{1} \mathbf{V}_{D 1} \cdot \mathbf{n} \\
\vdots \\
-\rho_{s} \mathbf{V}_{D S} \cdot \mathbf{n} \\
\vdots \\
-\rho \mathbf{V}_{D} \cdot \mathbf{n} \\
\boldsymbol{\tau} \cdot \mathbf{n} \\
\left(\mathbf{u} \cdot \boldsymbol{\tau}-\mathbf{q}-\sum \rho_{S} h_{S} \mathbf{V}_{D S}\right) \cdot \mathbf{n}
\end{array}\right], \quad \dot{W}=\left[\begin{array}{c}
\dot{w}_{1} \\
\vdots \\
\dot{w}_{S} \\
\vdots \\
\dot{w} \\
0 \\
0
\end{array}\right]
\end{gathered}
$$

\section{A. Turbulence Model}

Menter's Shear Stress Transport ${ }^{25}$ model (SST) was used in the current study. SST uses the $k-\varepsilon$ model near solid walls and transitions to $k-\omega$ model away from the walls with the help of a blending function. Details of the model are given below.

Kinematic Eddy Viscosity:

$$
v_{t}=\frac{a_{1} k}{\max \left(a_{1} \omega, \Omega F_{S S T}\right)}
$$

where $\Omega$ is the absolute value of the vorticity, $a_{1}=0.31$, and the blending function $F_{S S T}$ is given by:

$$
F_{S S T}=\tanh \left(\arg g_{S S T}^{2}\right)
$$

where

$$
\arg _{S S T}^{2}=\max \left(2 \frac{\sqrt{k}}{0.09 \omega y}, \frac{500 v}{y^{2} \omega}\right)
$$


Turbulent Stress Tensor:

$$
\tau_{i j}^{\prime}=\mu_{t}\left(\partial_{j} u_{i}+\partial_{i} u_{j}\right)-\frac{2}{3}\left(\mu_{t} \partial_{l} u_{l}+\rho k\right) \delta_{i j}
$$

Turbulent Kinetic Energy Equation:

$$
\partial_{t}(\rho k)+u_{l} \partial_{l}(\rho k)=\tau_{i j}^{\prime} \partial_{j} u_{i}-\beta^{*} \rho \omega k+\partial_{j}\left[\left(\mu+\mu_{t} \sigma_{k}\right) \partial_{j} k\right]
$$

Turbulent Dissipation Equation:

$$
\partial_{t}(\rho \omega)+u_{l} \partial_{l}(\rho \omega)=\frac{\gamma}{v_{t}} \tau_{i j}^{\prime} \partial_{j} u_{i}-\beta \rho \omega^{2}+\partial_{j}\left[\left(\mu+\mu_{t} \sigma_{\omega}\right) \partial_{j} \omega\right]+2\left(1-F_{S S T}\right) \rho \sigma_{\omega 2} \frac{1}{\omega} \partial_{j} k \partial_{j} \omega
$$

Coefficients:

$k-\omega$ and $k-\varepsilon$ model coefficients are blended as:

$$
\phi=F_{S S T} \phi_{k \omega}+\left(1-F_{S S T}\right) \phi_{k \varepsilon}
$$

where $\phi_{k \omega}$ are:

$$
\begin{gathered}
\sigma_{k 1}=0.85, \quad \sigma_{\omega 1}=0.5, \quad \beta_{1}=0.075, \quad \beta^{*}=0.09, \quad \kappa=0.41 \\
\gamma_{1}=\beta_{1} / \beta^{*}-\sigma_{\omega 1} \kappa^{2} / \sqrt{\beta^{*}}
\end{gathered}
$$

and $\phi_{k \varepsilon}$ are:

$$
\begin{gathered}
\sigma_{k 2}=1.0, \quad \sigma_{\omega 2}=0.856, \quad \beta_{2}=0.0828, \quad \beta^{*}=0.09, \quad \kappa=0.41, \\
\gamma_{2}=\beta_{2} / \beta^{*}-\sigma_{\omega 2} \kappa^{2} / \sqrt{\beta^{*}}
\end{gathered}
$$

Law-of-the-Wall:

The well-known law-of-the-wall function treatment ${ }^{26}$ that includes the log layer, viscous sublayer and transition is optionally used when grid spacing near walls is not fine enough to yield $y^{+}<1$.

\section{B. Chemistry Model}

$N R$ chemical reactions involving $N S$ species can be written in general terms as:

$$
v_{1, r}^{\prime} X_{1}+\cdots+v_{s, r}^{\prime} X_{S}+\cdots+v_{N S, r}^{\prime} X_{N S} \leftrightarrow v_{1, r}^{\prime \prime} X_{1}+\cdots+v_{s, r}^{\prime \prime} X_{S}+\cdots+v_{N S, r}^{\prime \prime} X_{N S}, \quad r=1, \ldots, N R
$$

The source term can be expressed as:

$$
\dot{w}_{s}=\left(\frac{d \rho_{s}}{d t}\right)_{\text {chemistry }}=M_{s} \sum_{r=1}^{N R}\left(v_{s, r}^{\prime \prime}-v_{s, r}^{\prime}\right) \times\left[k_{f, r} \prod_{l=1}^{N S}\left(\frac{\rho_{l}}{M_{l}}\right)^{v_{l, r}^{\prime}}-k_{b, r} \prod_{l=1}^{N S}\left(\frac{\rho_{l}}{M_{l}}\right)^{v_{l, r}^{\prime \prime}}\right]=
$$

The forward reaction rates are determined with the Arrhenius relation:

$$
k_{f, r}=C T^{\eta} e^{-\theta / T}
$$

Backward reaction rates are determined using the equilibrium constant, $K_{e, r}$ :

$$
k_{b, r}=\frac{k_{f, r}}{K_{e, r}}
$$

In the current formulation, chemistry is taken as laminar. Fluctuating part of the reaction rate as determined by the Arrhenius relation, Eq. (14), is not considered. However, species diffusivities and thermal conductivity are modified using the eddy viscosity, a turbulent Schmidt number of 0.7 and a turbulent Prandtl number of 0.9.

Four different $\mathrm{H}_{2} / \mathrm{O}_{2}$ chemistry mechanisms are evaluated. Reactions along with forward Arrhenius rate coefficients $C, \eta, \theta$ as used in Eq. (14) are detailed in Table 2. While the different mechanisms chosen here share many common reactions, the reaction rates vary significantly in accordance with the original derivation conditions. The conditions under which $6 \mathrm{~s} 9 \mathrm{r}^{18}$ and $6 \mathrm{~s} 8 \mathrm{r}^{27}$ mechanism rates were determined could not be tracked down. On the other hand, the $8 \mathrm{~s} 9 \mathrm{r}^{28}$ mechanism targets high pressure combustion cases whereas $8 \mathrm{~s} 19 \mathrm{r}^{29}$ mechanism was validated for a large range of pressures. 
Table 2 Forward Arrhenius rate coefficients of evaluated reaction mechanisms.

\begin{tabular}{|c|c|c|c|c|c|c|c|}
\hline \multicolumn{8}{|c|}{ (6s9r) - 6 species, 9 reactions mechanism used by Mack et al. ${ }^{18}$} \\
\hline Reaction & $\underset{m^{3} /(k m o l . s)}{C}$ & $\boldsymbol{\eta}$ & $\boldsymbol{\theta}$ & Reaction & $\begin{array}{c}\boldsymbol{C} \\
\mathrm{m}^{3} /(\text { kmol.s })\end{array}$ & $\boldsymbol{\eta}$ & $\boldsymbol{\theta}$ \\
\hline $\mathrm{H}_{2}+\mathrm{O}_{2} \leftrightarrow 2 \mathrm{OH}$ & $1.7 \times 10^{10}$ & 0 & 24,070 & $H+O+M \leftrightarrow O H+M$ & $1 \times 10^{10}$ & 0 & 0 \\
\hline $\mathrm{H}_{2}+\mathrm{OH} \leftrightarrow \mathrm{H}_{2} \mathrm{O}+\mathrm{H}$ & $2.19 \times 10^{10}$ & 0 & 2,590 & $2 O+M \leftrightarrow O_{2}+M$ & $2.55 \times 10^{12}$ & -1 & 59,390 \\
\hline $2 \mathrm{OH} \leftrightarrow \mathrm{H}_{2} \mathrm{O}+\mathrm{O}$ & $6.023 \times 10^{9}$ & 0 & 550 & $2 H+M \leftrightarrow H_{2}+M$ & $5 \times 10^{9}$ & 0 & 0 \\
\hline $\mathrm{H}_{2}+\mathrm{O} \leftrightarrow \mathrm{OH}+\mathrm{O}$ & $1.8 \times 10^{7}$ & 1 & 4,480 & $\mathrm{OH}+\mathrm{H}+\mathrm{M} \leftrightarrow \mathrm{H}_{2} \mathrm{O}+\mathrm{M}$ & $8.4 \times 10^{15}$ & -2 & 0 \\
\hline $\mathrm{O}_{2}+\mathrm{H} \leftrightarrow \mathrm{OH}+\mathrm{O}$ & $1.22 \times 10^{14}$ & -0.91 & 8,369 & & & & \\
\hline \multicolumn{8}{|c|}{ (6s8r) - 6 species, 8 reactions mechanism by Evans and Schexnayder ${ }^{27}$} \\
\hline Reaction & $\begin{array}{c}\boldsymbol{C} \\
\mathrm{m}^{3} /(\mathrm{kmol} . \mathrm{s}) \\
\end{array}$ & $\boldsymbol{\eta}$ & $\boldsymbol{\theta}$ & Reaction & $\begin{array}{c}\boldsymbol{C} \\
m^{3} /(\text { kmol.s }) \\
\end{array}$ & $\boldsymbol{\eta}$ & $\boldsymbol{\theta}$ \\
\hline$H_{2}+M \leftrightarrow 2 H+M$ & $5.5 \times 10^{15}$ & -1 & 51,987 & $\mathrm{H}_{2} \mathrm{O}+\mathrm{O} \leftrightarrow 2 \mathrm{OH}$ & $5.8 \times 10^{10}$ & 0 & 9,059 \\
\hline$O_{2}+M \leftrightarrow 2 O+M$ & $7.2 \times 10^{15}$ & -1 & 59,340 & $\mathrm{H}_{2} \mathrm{O}+\mathrm{H} \leftrightarrow \mathrm{OH}+\mathrm{H}_{2}$ & $8.4 \times 10^{10}$ & 0 & 10,116 \\
\hline $\mathrm{H}_{2} \mathrm{O}+\mathrm{M} \leftrightarrow \mathrm{OH}+\mathrm{H}+\mathrm{M}$ & $5.2 \times 10^{18}$ & -1.5 & 59,386 & $\mathrm{O}_{2}+\mathrm{H} \leftrightarrow \mathrm{OH}+\mathrm{O}$ & $2.2 \times 10^{11}$ & 0 & 8,455 \\
\hline$O H+M \leftrightarrow O+H+M$ & $8.5 \times 10^{15}$ & -1 & 50,830 & $\mathrm{H}_{2}+\mathrm{O} \leftrightarrow \mathrm{OH}+\mathrm{H}$ & $7.5 \times 10^{10}$ & 0 & 5,586 \\
\hline \multicolumn{8}{|c|}{ (8s9r) - 8 species, 9 reactions mechanism by Gontkovskaya et al. ${ }^{28}$} \\
\hline Reaction & $\begin{array}{c}\boldsymbol{C} \\
\mathrm{m}^{3} /(\text { kmol.s }) \\
\end{array}$ & $\boldsymbol{\eta}$ & $\boldsymbol{\theta}$ & Reaction & $\begin{array}{c}\boldsymbol{C} \\
\mathrm{m}^{3} /(\mathrm{kmol.s}) \\
\end{array}$ & $\boldsymbol{\eta}$ & $\boldsymbol{\theta}$ \\
\hline $\mathrm{H}_{2}+\mathrm{O}_{2} \leftrightarrow 2 \mathrm{OH}$ & $2.52 \times 10^{9}$ & 0 & 4,691 & $\mathrm{OH}+\mathrm{H}_{2} \leftrightarrow \mathrm{H}_{2} \mathrm{O}+\mathrm{H}$ & $2.25 \times 10^{10}$ & 0 & 630 \\
\hline $\mathrm{H}+\mathrm{O}_{2} \leftrightarrow \mathrm{OH}+\mathrm{O}$ & $1.55 \times 10^{11}$ & 0 & 2,009 & $\mathrm{H}_{2}+\mathrm{O} \leftrightarrow \mathrm{OH}+\mathrm{H}$ & $2.46 \times 10^{10}$ & 0 & 1,183 \\
\hline $2 H+M \leftrightarrow H_{2}+M$ & $3.6 \times 10^{12}$ & 0 & 0 & $H+\mathrm{O}_{2}+\mathrm{M} \leftrightarrow \mathrm{HO}_{2}+\mathrm{M}$ & $3.6 \times 10^{12}$ & 0 & 0 \\
\hline $2 \mathrm{OH}+\mathrm{M} \leftrightarrow \mathrm{H}_{2} \mathrm{O}_{2}+\mathrm{M}$ & $1.11 \times 10^{13}$ & 0 & 231 & $\mathrm{HO}_{2}+\mathrm{HO}_{2} \leftrightarrow \mathrm{H}_{2} \mathrm{O}_{2}+\mathrm{O}_{2}$ & $1 \times 10^{10}$ & 0 & 0 \\
\hline $\mathrm{H}+\mathrm{H}_{2} \mathrm{O}_{2} \leftrightarrow \mathrm{H}_{2}+\mathrm{HO}_{2}$ & $1.17 \times 10^{11}$ & 0 & 1,419 & & & & \\
\hline \multicolumn{8}{|c|}{ (8s19r) - 8 species, 19 reactions mechanism by Ó Conaire et al. ${ }^{29}$} \\
\hline Reaction & $\begin{array}{c}\boldsymbol{C} \\
\mathrm{m}^{3} /(\mathrm{kmol} . \mathrm{s}) \\
\end{array}$ & $\boldsymbol{\eta}$ & $\boldsymbol{\theta}$ & Reaction & $\begin{array}{c}\boldsymbol{C} \\
\mathrm{m}^{3} /(\mathrm{kmol.s}) \\
\end{array}$ & $\boldsymbol{\eta}$ & $\boldsymbol{\theta}$ \\
\hline $\mathrm{H}+\mathrm{O}_{2} \leftrightarrow \mathrm{O}+\mathrm{OH}$ & $1.91 \times 10^{11}$ & 0 & 8,273 & $\mathrm{HO}_{2}+\mathrm{O} \leftrightarrow \mathrm{OH}+\mathrm{O}_{2}$ & $3.25 \times 10^{10}$ & 0 & 0 \\
\hline $\mathrm{O}+\mathrm{H}_{2} \leftrightarrow \mathrm{H}+\mathrm{OH}$ & $5.08 \times 10^{1}$ & 2.67 & 3,166 & $\mathrm{HO}_{2}+\mathrm{OH} \leftrightarrow \mathrm{H}_{2} \mathrm{O}+\mathrm{O}_{2}$ & $2.89 \times 10^{10}$ & 0 & -251.6 \\
\hline $\mathrm{OH}+\mathrm{H}_{2} \leftrightarrow \mathrm{H}+\mathrm{H}_{2} \mathrm{O}$ & $2.16 \times 10^{5}$ & 1.51 & 1,726 & $\mathrm{HO}_{2}+\mathrm{HO}_{2} \leftrightarrow \mathrm{H}_{2} \mathrm{O}_{2}+\mathrm{O}_{2}$ & $4.2 \times 10^{11}$ & 0 & 6,029 \\
\hline $\mathrm{O}+\mathrm{H}_{2} \mathrm{O} \leftrightarrow 2 \mathrm{OH}$ & $2.97 \times 10^{3}$ & 2.02 & 6,743 & $\mathrm{HO}_{2}+\mathrm{HO}_{2} \leftrightarrow \mathrm{H}_{2} \mathrm{O}_{2}+\mathrm{O}_{2}$ & $1.3 \times 10^{8}$ & 0 & -819.7 \\
\hline$H_{2}+M \leftrightarrow 2 H+M$ & $4.57 \times 10^{16}$ & -1.4 & 52,890 & $\mathrm{H}_{2} \mathrm{O}_{2}+\mathrm{M} \leftrightarrow 2 \mathrm{OH}+\mathrm{M}$ & $1.27 \times 10^{14}$ & 0 & 22,900 \\
\hline $2 O+M \leftrightarrow O_{2}+M$ & $6.17 \times 10^{12}$ & -0.5 & 0 & $\mathrm{H}_{2} \mathrm{O}_{2} \leftrightarrow 2 \mathrm{OH}$ & $2.95 \times 10^{11}$ & 0 & 24,360 \\
\hline$O+H+M \leftrightarrow O H+M$ & $4.72 \times 10^{15}$ & -1 & 0 & $\mathrm{H}_{2} \mathrm{O}_{2}+\mathrm{H} \leftrightarrow \mathrm{H}_{2} \mathrm{O}+\mathrm{OH}$ & $2.41 \times 10^{10}$ & 0 & 1,998 \\
\hline $\mathrm{H}+\mathrm{OH}+\mathrm{M} \leftrightarrow \mathrm{H}_{2} \mathrm{O}+\mathrm{M}$ & $4.5 \times 10^{19}$ & -2 & 0 & $\mathrm{H}_{2} \mathrm{O}_{2}+\mathrm{H} \leftrightarrow \mathrm{H}_{2}+\mathrm{HO}_{2}$ & $6.03 \times 10^{10}$ & 0 & 4,001 \\
\hline$H+\mathrm{O}_{2}+\mathrm{M} \leftrightarrow \mathrm{HO}_{2}+\mathrm{M}$ & $3.48 \times 10^{13}$ & -0.41 & -563 & $\mathrm{H}_{2} \mathrm{O}_{2}+\mathrm{O} \leftrightarrow \mathrm{OH}+\mathrm{HO}_{2}$ & $9.55 \times 10^{3}$ & 2 & 1,998 \\
\hline $\mathrm{H}+\mathrm{O}_{2} \leftrightarrow \mathrm{HO}_{2}$ & $1.48 \times 10^{9}$ & 0.6 & 0 & $\mathrm{H}_{2} \mathrm{O}_{2}+\mathrm{OH} \leftrightarrow \mathrm{H}_{2} \mathrm{O}+\mathrm{HO}_{2}$ & $1 \times 10^{9}$ & 0 & 0 \\
\hline $\mathrm{HO}_{2}+\mathrm{H} \leftrightarrow \mathrm{H}_{2}+\mathrm{O}_{2}$ & $1.66 \times 10^{10}$ & 0 & 412.6 & $\mathrm{H}_{2} \mathrm{O}_{2}+\mathrm{OH} \leftrightarrow \mathrm{H}_{2} \mathrm{O}+\mathrm{HO}_{2}$ & $5.8 \times 10^{11}$ & 0 & 4,811 \\
\hline $\mathrm{HO}_{2}+\mathrm{H} \leftrightarrow 2 \mathrm{OH}$ & $7.08 \times 10^{10}$ & 0 & 151 & & & & \\
\hline
\end{tabular}

\section{Test Cases}

Two different single element injectors are investigated. The first test case is based on the experiments conducted by Vaidyanathan et al. ${ }^{23}$. Experimental setup consists of a $\mathrm{GH}_{2} / \mathrm{GO}_{2}$ single element shear coaxial injector and a rectangular combustion chamber to allow for optical access through quartz windows. The corners are rounded to withstand the high pressure. The setup is shown in Figure 1 and details of the two cases are listed in Table 3. Wall heat flux and OH-PLIF measurements were taken. Wall heat flux values are calculated using temperature readings at $3.2 \mathrm{~mm}$ and $9.5 \mathrm{~mm}$ distances from the inner wall.

A schematic of the computational domain is shown in Figure 2. $1 / 8^{\text {th }}$ section of the combustion chamber is modeled. A constant temperature of $500 \mathrm{~K}$ is imposed on the chamber wall while the injector face plate is assumed adiabatic. While these imposed conditions are unrealistic, the correct conditions are not normally available for cases without prior experimental measurements. Thus it is chosen here to stay independent of experimental measurements in setting up the boundary conditions. An exception is the chamber pressure which is fixed to its experimentally observed value via a pressure outlet condition. Note that the correct value could be reproduced independently by extending the domain to include the exit nozzle at the expense of additional computational cost. Uniform mass flux 
profiles of $\mathrm{H}_{2}$ and $\mathrm{O}_{2}$ are imposed at the inlets with the values listed in Table 3. The inlet temperatures are taken as $300 \mathrm{~K}$. Note that this is only for the purposes of the current sensitivity study. In simulations to follow with input from this study, injector nozzle flow is to be included in the simulations.

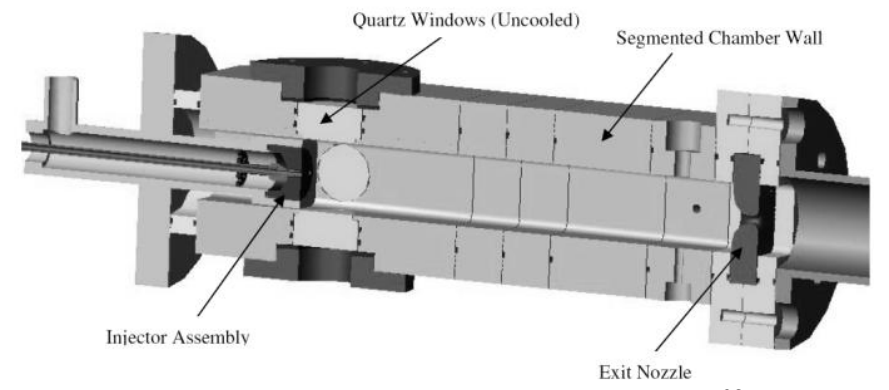

\begin{tabular}{ll}
\hline Cross section & $25.4 \mathrm{~mm} \times 25.4 \mathrm{~mm}$ \\
Corner radius & $3 \mathrm{~mm}$ \\
Chamber length & $169.3 \mathrm{~mm}$ \\
\hline
\end{tabular}

Figure 1 Vaidyanathan et al. ${ }^{23}$ combustion chamber configuration.

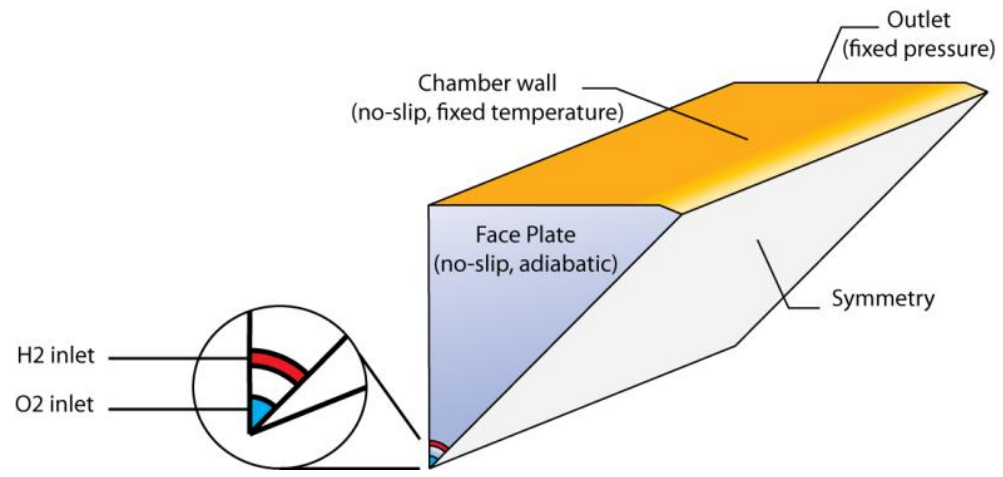

Figure 2 Computational domain for Vaidyanathan et al. ${ }^{23}$ injector.

The second test case is based on the measurements reported by Pal et al. ${ }^{22}$. The experimental setup consists of a single element shear coaxial injector, a main cylindrical combustion chamber and two $\mathrm{GO}_{2} / \mathrm{GH}_{2}$ preburners which provide hot, oxidizer-rich and fuel-rich streams. A schematic of their experimental setup is shown in Figure 3 . The main chamber wall is instrumented with coaxial heat flux gauges which provide both temperature and heat flux profiles. Details of the experimental conditions are given in Table 3, a complete description is provided by Pal et $\mathrm{al}^{22}$.

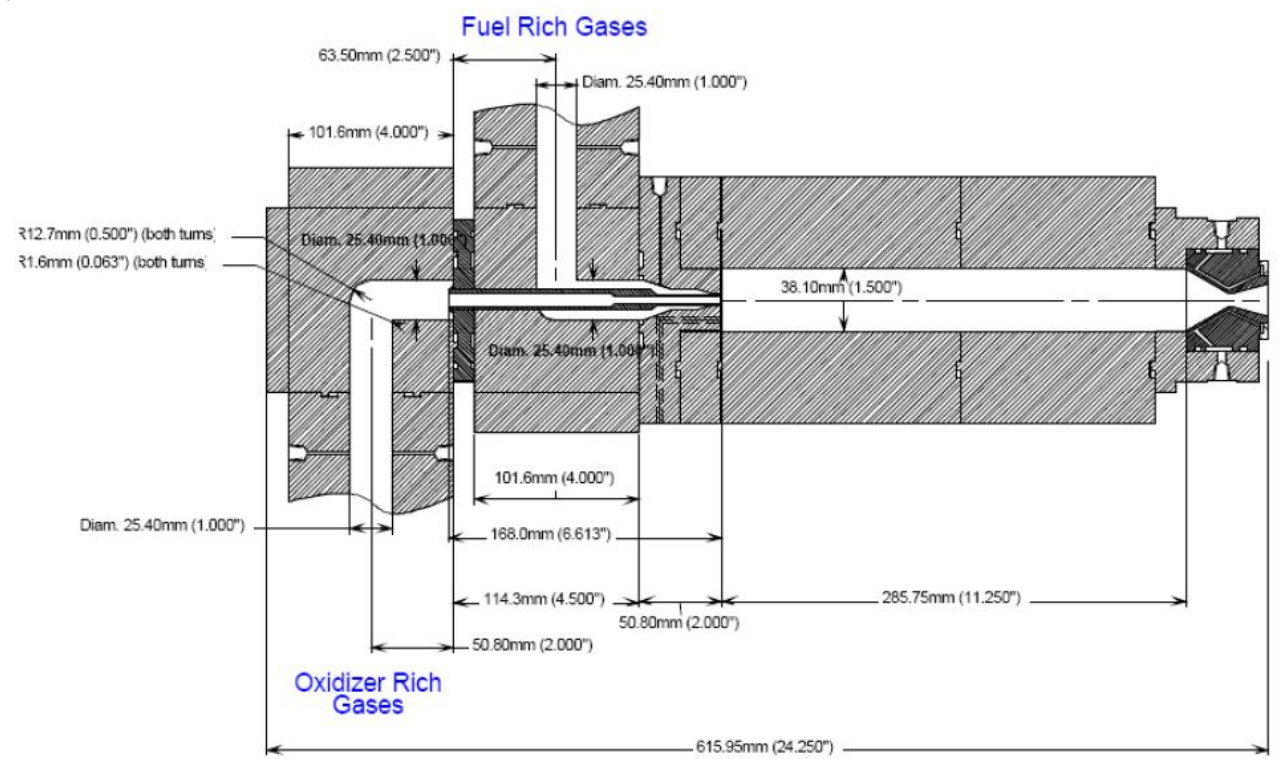

Figure 3 Pal et al. ${ }^{22}$ injector setup schematic.

American Institute of Aeronautics and Astronautics 
Computational domain and boundary condition types for the Pal et al. ${ }^{22}$ injector are depicted in Figure 4. Axisymmetric domain is modeled with a 1-degree pie shaped grid (circumferential dimension is exaggerated in Figure 4 for clarity). For the chamber wall thermal boundary condition, options of assigning a constant temperature or prescribing the measured temperature profile are evaluated whereas face plate and exit nozzle temperatures are set to upstream and downstream ends of the measured wall temperature data respectively. As opposed to the Vaidyanathan et al. ${ }^{23}$ test case, both inlet and exit nozzles are included in the domain. An extrapolated boundary condition is used at the supersonic exit, so the chamber pressure is not imposed but followed from the solution.

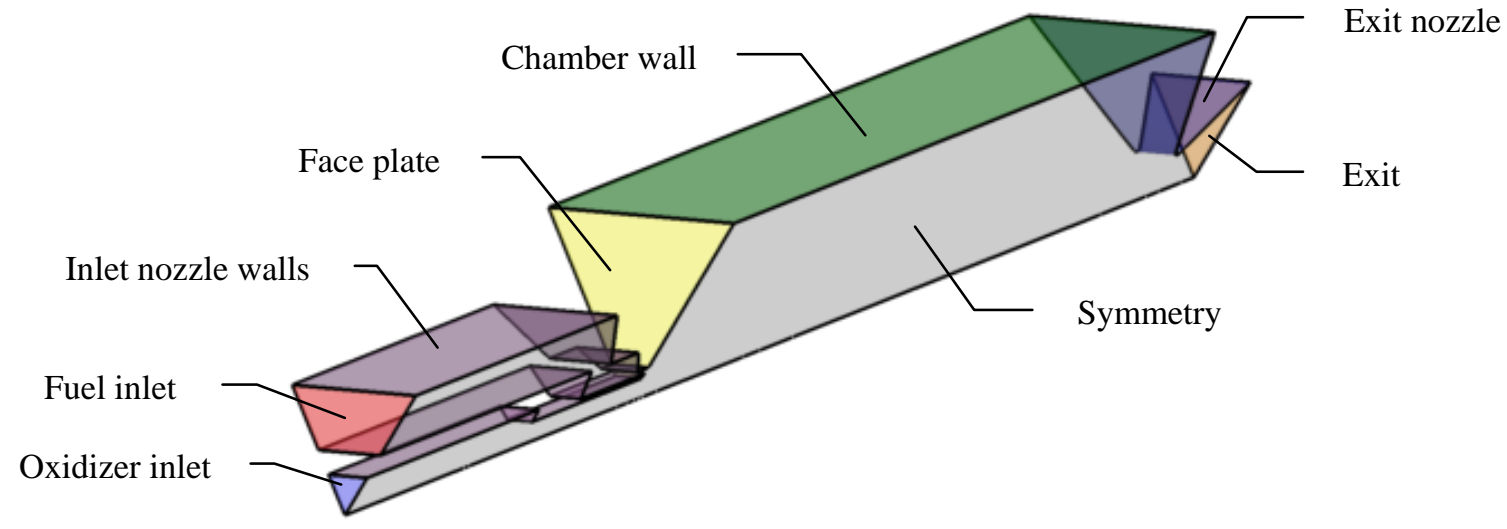

Thermal Boundary Conditions

\begin{tabular}{|c|c|c|c|}
\hline Inlet nozzle walls & Face plate & Chamber wall & Exit nozzle wall \\
\hline Adiabatic & Constant $\mathrm{T}=754 \mathrm{~K}$ & $\begin{array}{c}\text { Constant } \mathrm{T}=700 \mathrm{~K} \\
\text { or } \\
\text { experimental profile }\end{array}$ & Constant $\mathrm{T}=510 \mathrm{~K}$ \\
\hline
\end{tabular}

Figure 4 Computational domain schematic and thermal boundary conditions for Pal et al. ${ }^{22}$ injector.

Table 3 Details of the test cases.

\begin{tabular}{|c|c|c|c|}
\hline & & Vaidyanathan et al. ${ }^{23}$ & Pal et al. ${ }^{22}$ \\
\hline & Oxidizer post inner diameter $(\mathrm{mm})$ & 1.2 & 5.26 \\
\hline & Oxidizer post thickness (mm) & 1 & 1.04 \\
\hline & Fuel annulus diameter (mm) & 2.69 & 7.49 \\
\hline & Chamber height (mm) & 25.4 & 38.1 \\
\hline & Chamber length (mm) & 169 & 286 \\
\hline \multirow{4}{*}{ 焉 } & Fuel mass flux (g/s) & 0.58 & 33.1 \\
\hline & $\mathrm{H}_{2}$ mass fraction in fuel & 1 & 0.402 \\
\hline & Velocity (m/s) & 103.5 & 740 \\
\hline & Temperature (K) & 300 & 811 \\
\hline \multirow{7}{*}{ 矛 } & Oxidizer mass flux (g/s) & 2.198 & 90.4 \\
\hline & $\mathrm{O}_{2}$ mass fraction in oxidizer & 1 & 0.945 \\
\hline & Velocity $(\mathrm{m} / \mathrm{s})$ & 41.4 & 146 \\
\hline & Temperature (K) & 300 & 700 \\
\hline & Equivalence ratio & 2.11 & 1.24 \\
\hline & Fuel/Oxidizer velocity ratio & 2.5 & 5.07 \\
\hline & Chamber pressure (bars) & 37 & 54.2 \\
\hline
\end{tabular}


The investigation of Pal et al. ${ }^{22}$, compared to that of Vaidyanathan et al. ${ }^{23}$, is conducted on a larger chamber with hot fuel and oxidizer being injected in significantly higher velocities resulting in a larger chamber pressure. Also, fuel/oxidizer velocity ratio is twice as high as the Vaidyanathan et $\mathrm{al}^{23}$ case.

\section{Results and Discussions}

Table 4 provides a summary of the numerical test matrix for each case. The results and discussions are provided for each test in the following sections.

Table 4 Summary of numerical tests.

\begin{tabular}{lcc}
\hline Test Item & Vaidyanathan et al. $^{\mathbf{2 3}}$ & Pal et al. $^{\mathbf{2 2}}$ \\
\hline Grid resolution levels & 5 & 3 \\
& $6 \mathrm{~s} 9 \mathrm{r}$ & \\
Chemistry mechanisms & $6 \mathrm{~s} 8 \mathrm{r}$ & $6 \mathrm{~s} 8 \mathrm{r}$ \\
& $8 \mathrm{~s} 9 \mathrm{r}$ & $8 \mathrm{~s} 19 \mathrm{r}$ \\
Law-of-the-wall vs. integrating to the wall & $8 \mathrm{~s} 19 \mathrm{r}$ & $\checkmark$ \\
Constant wall temperature vs. using experimental profile & $\boldsymbol{x}$ & $\checkmark$
\end{tabular}

\section{A. Vaidyanathan et al. ${ }^{23}$ Injector}

\section{Grid Resolution Sensitivity}

The accuracy of the CFD simulations largely rely on sufficient resolution of the flow features by the computational grid. Ideally, the grid should be fine enough that upon further refinement, solution is virtually unchanged. With obvious concerns for the computational cost on the other hand, an initial coarse grid was progressively refined and tested to reach the grid insensitive level without overkill.

The grids used consist of tetrahedral cells with slender prisms for the top wall boundary layer and pyramids for transition between prisms and tetrahedra. Cells are clustered near the $\mathrm{H}_{2} / \mathrm{O}_{2}$ inlets and the mixing layer. Five different grids were tested to assess the sensitivity of simulations to grid resolutions. Figure 5 shows two views of the coarsest grid.
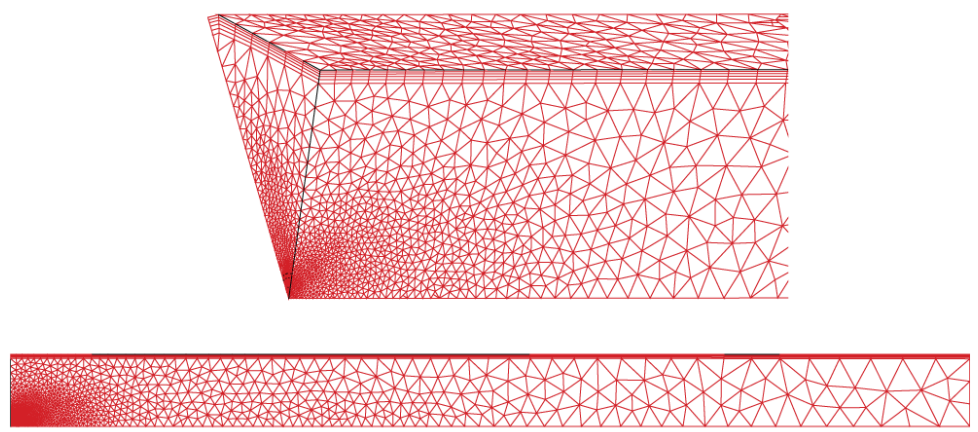

Figure 5 Two views of the coarsest grid ( $51 \mathrm{~K}$ cells) for Vaidyanathan et al. ${ }^{23}$ injector.

Table 5 lists the total number of cells for each grid. Each level of refinement corresponds to a decrease in cell sizes by a factor of approximately 1.5 as uniformly as the unstructured context allows. Although grid 5 has less total number of cells compared to grid 4 , it is refined in critical regions and coarsened elsewhere guided by the experience drawn from previous simulations.

Table 5 Grid Sizes

\begin{tabular}{lccccc}
\hline Grid no & 1 & 2 & 3 & 4 & 5 \\
\hline Number of cells & $51 \mathrm{~K}$ & $217 \mathrm{~K}$ & $740 \mathrm{~K}$ & $2,214 \mathrm{~K}$ & $2,003 \mathrm{~K}$ \\
\hline
\end{tabular}


Figure 6 Temperature contours for different grid resolutions (Vaidyanathan et al. ${ }^{23}$ injector).

Figure 6 shows a comparative view of the temperature field outcomes of the tested grids. As the grid is progressively refined, three general trends can immediately be observed:

- Flame is less dispersed,

- Although the combustion lengths are similar, flame merges to the centerline farther downstream,

- Upper left quadrant of the domain attains slightly lower temperatures.

Centerline $\mathrm{OH}$ mass fraction distributions are shown in and Figure 7. The distributions shown provide indications of flame length and location of flame merge to the centerline which translates to how fast mixing of the fuel and oxidizer streams occur. Figure 7 confirms the observation that insufficient grid resolution results in a more dispersed flame and earlier mixing compared to the finer grid solutions. Grid 3 to Grid 5 show consistent prediction of the peak $\mathrm{OH}$ mass fraction at the centerline and only slightly different merge locations.

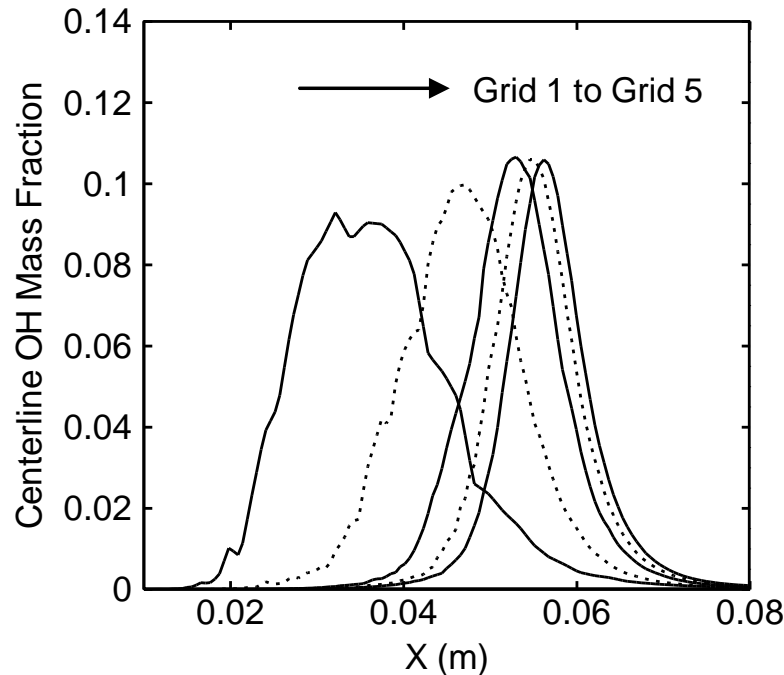

Figure 7 Centerline $\mathrm{OH}$ mass fraction distributions for different grid resolutions

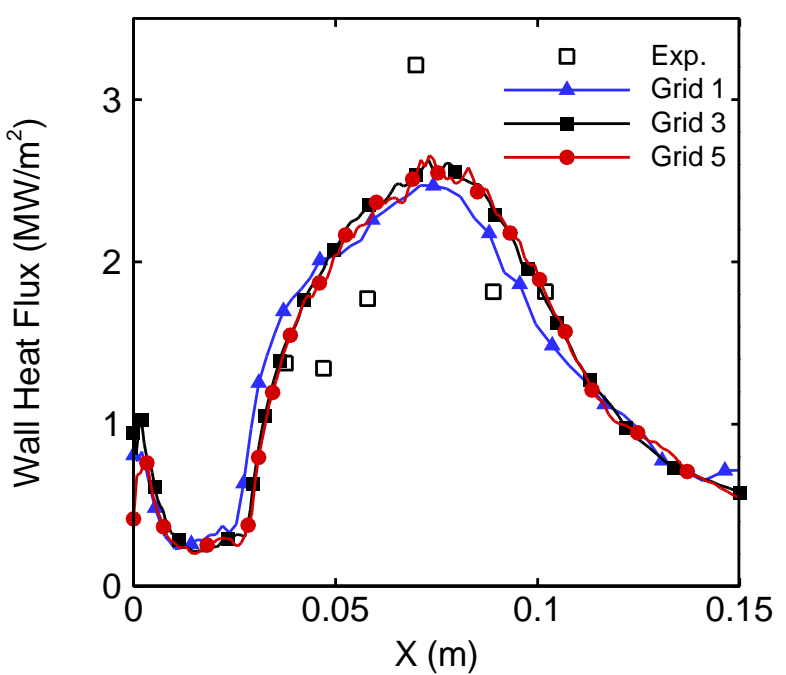

Figure 8 Chamber wall heat flux distributions for different grid resolutions 
Figure 8 on the other hand compares the chamber wall heat flux distributions. Grid 2 and Grid 4 results are skipped for the sake of clarity as the results are practically identical to those of Grid 3 and Grid 5. Grid 1exhibits slightly smaller peak heat flux value as well as a slight shift of the profile towards downstream. Overall, the wall heat flux feature proved largely insensitive to the grid resolution. This is also evident from the very similar near wall temperature distributions shows in Figure 6.

Note that the chamber wall is placed 4.2 outer injector diameters away from the injector. A large vortex on the upper left quadrant entraining part of the fuel stream cools the upstream portion of the wall. It is only when the stream attaches to the wall that the heat from the flame is transmitted to the wall. Thus the location and value of the peak heat flux is largely independent of how well the flame is resolved but it depends more on whether the total energy output of the flame is predicted well. Figure 9 demonstrates these points.

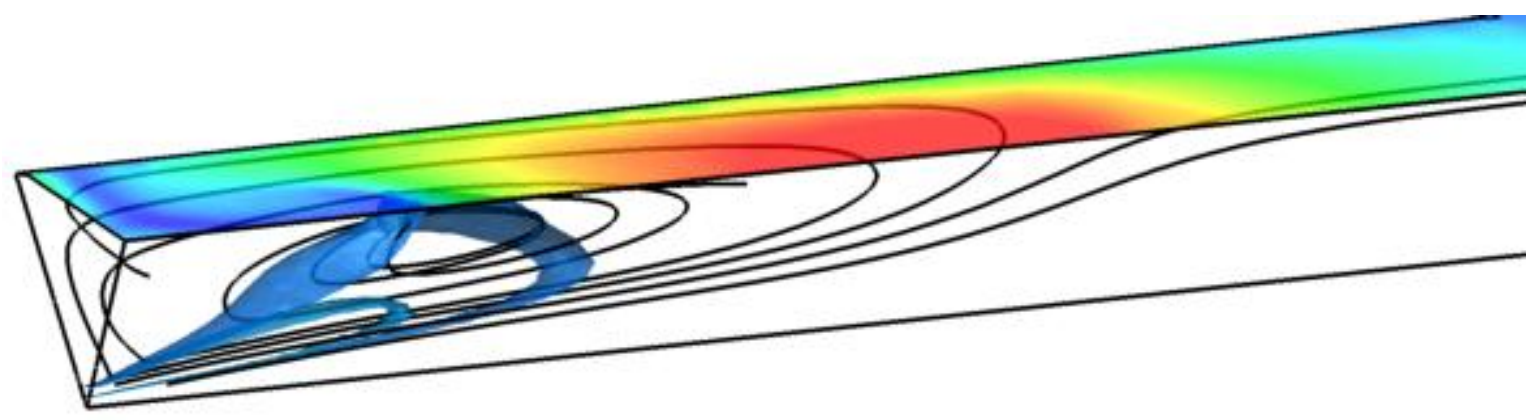

Figure 9 A 3D view of the solution (Vaidyanathan et al. ${ }^{23}$ injector). Top wall contours: heat flux, Isosurfaces: correspond to $\mathrm{OH}$ mass fractions of 0.16 (outer) and 0.2 (inner).

\section{Sensitivity to Chemistry Mechanism}

Reduced reaction mechanisms for a particular chemistry is generally derived and validated for specific types of problems and ranges of pressure, mixedness, etc. Hence they are not universally applicable. As detailed in Table 2 before, four different $\mathrm{H}_{2} / \mathrm{O}_{2}$ reaction mechanisms are chosen to be evaluated. Table 6 lists some common reactions between them and gives reaction rate constants at $3000 \mathrm{~K}$ temperature as calculated via Eq. (14). Entries in the table are shaded based on the calculated rate constants; darker color corresponding to higher rates. The entries labeled as "reverse" give reverse reaction rate constants as the forward rate coefficients are not available.

Table 6 Rate constants in $\mathrm{m}^{3} /(\mathrm{kmol} . \mathrm{s})$ calculated at $3000 \mathrm{~K}$ temperature for some common reactions between different chemistry mechanisms.

\begin{tabular}{|c|c|c|c|c|}
\hline & $6 \mathrm{~s} 9 \mathrm{r}$ & $6 s 8 r$ & $8 s 9 r$ & 8s19r \\
\hline $\mathrm{H}_{2}+\mathrm{O}_{2} \leftrightarrow 2 \mathrm{OH}$ & $5.57 \times 10^{6}$ & - & $5.3 \times 10^{8}$ & - \\
\hline $\mathrm{OH}+\mathrm{H}_{2} \leftrightarrow \mathrm{H}_{2} \mathrm{O}+\mathrm{H}$ & $9.2 \times 10^{9}$ & reverse: $2.9 \times 10^{9}$ & $1.8 \times 10^{10}$ & $2.2 \times 10^{10}$ \\
\hline $\mathrm{H}_{2} \mathrm{O}+\mathrm{O} \leftrightarrow 2 \mathrm{OH}$ & reverse: $5 \times 10^{9}$ & $2.8 \times 10^{9}$ & - & $3.3 \times 10^{9}$ \\
\hline$H_{2}+O \leftrightarrow O H+H$ & $1.2 \times 10^{10}$ & $1.2 \times 10^{10}$ & $1.7 \times 10^{10}$ & $3.4 \times 10^{10}$ \\
\hline $\mathrm{O}_{2}+\mathrm{H} \leftrightarrow \mathrm{OH}+\mathrm{O}$ & $5.1 \times 10^{9}$ & $1.3 \times 10^{10}$ & $7.9 \times 10^{10}$ & $1.2 \times 10^{10}$ \\
\hline$O+H+M \leftrightarrow O H+M$ & $1 \times 10^{10}$ & reverse: $1.2 \times 10^{5}$ & - & $1.6 \times 10^{12}$ \\
\hline $2 O+M \leftrightarrow O_{2}+M$ & 2.1 & reverse: $6.2 \times 10^{3}$ & - & $1.1 \times 10^{11}$ \\
\hline$H_{2}+M \leftrightarrow 2 H+M$ & reverse: $5 \times 10^{9}$ & $5.46 \times 10^{4}$ & reverse: $3.6 \times 10^{12}$ & $1.4 \times 10^{4}$ \\
\hline $\mathrm{H}+\mathrm{OH}+\mathrm{M} \leftrightarrow \mathrm{H}_{2} \mathrm{O}+\mathrm{M}$ & $9.3 \times 10^{8}$ & reverse: $8 \times 10^{4}$ & - & $5 \times 10^{12}$ \\
\hline $2 \mathrm{HO}_{2} \leftrightarrow \mathrm{H}_{2} \mathrm{O}_{2}+\mathrm{O}_{2}$ & - & - & $1 \times 10^{10}$ & $5.6 \times 10^{10}$ \\
\hline $\mathrm{H}_{2} \mathrm{O}_{2}+\mathrm{H} \leftrightarrow \mathrm{H}_{2}+\mathrm{HO}_{2}$ & - & - & $7.3 \times 10^{10}$ & $1.6 \times 10^{10}$ \\
\hline$H+\mathrm{O}_{2}+M \leftrightarrow H O_{2}+M$ & - & - & $3.6 \times 10^{12}$ & $1.6 \times 10^{12}$ \\
\hline
\end{tabular}

At the test temperature of $3000 \mathrm{~K}$, individual reaction steps belonging to the 8 species mechanisms $(8 \mathrm{~s} 9 \mathrm{r}$ and 8 s19r) exhibit a trend of larger rate constants but still staying on the same order. The third body reactions, on the 
other hand, show greater variation in rate constants. To have a more quantitative idea about the response time scales of these mechanisms, we follow a test procedure such as:

1. Sample thermodynamic state of an in-flame point from one of the current simulations,

2. Perturb the sampled thermodynamic state by introducing $20 \%$ additional $\mathrm{O}_{2}$,

3. Integrate the 4 different reaction mechanisms in time until convergence to a new equilibrium state.

The perturbed state (step 2) is listed in Table 7. Results of the step 3 is presented in Figure 10 as the time history of species mass fractions.

Table 7 Thermodynamic state of sampled in-flame point perturbed by $20 \% \mathrm{O}_{2}$ addition.

\begin{tabular}{cccccccc}
\hline & & \multicolumn{7}{c}{ Mass Fractions } \\
Pressure (bar) & Temperature (K) & $\mathrm{H}_{2}$ & $\mathrm{O}_{2}$ & $\mathrm{OH}$ & $\mathrm{O}$ & $\mathrm{H}$ & $\mathrm{H}_{2} \mathrm{O}$ \\
\hline 37 & 3000 & 0.06793 & 0.000326 & 0.01936 & 0.00117 & 0.00148 & 0.90733 \\
\hline
\end{tabular}
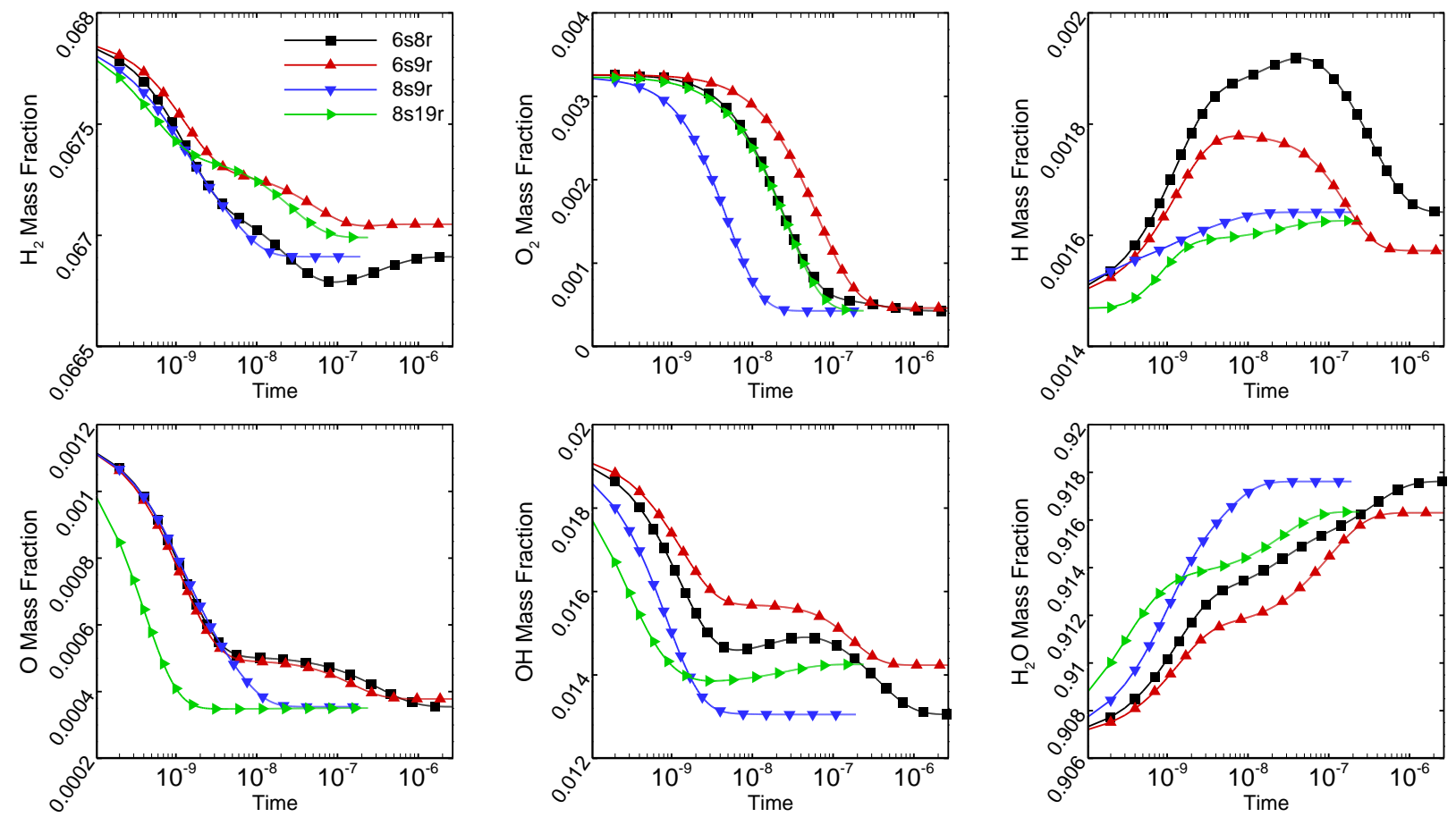

Figure 10 Time history of reaction mechanism responses.

Note that the state listed in Table 7 is still fuel rich. So the additional oxygen drives the reactions towards consuming some of the available $\mathrm{H}_{2}$, producing more $\mathrm{H}$ and $\mathrm{H}_{2} \mathrm{O}$. An interesting observation is that compared to 6s9r and 8s $19 \mathrm{r}$ mechanisms, the 6s8r and 8s9r mechanisms consumed the same amount of $\mathrm{O}_{2}$, but consumed more of $\mathrm{H}_{2}$ resulting in higher $\mathrm{H}$ and $\mathrm{H}_{2} \mathrm{O}$ with lower $\mathrm{OH}$ levels. Even when two particular chemistry mechanisms have the same set of reaction steps, with possibly different rates, their equilibrium state for a given condition can be different due to the different interplay between the individual reaction steps. In this case, although disparities between the new equilibrium states exist, the magnitude of the difference is minute.

Figure 10 also demonstrates that there is a noticeable disparity between the time scales of the 8 species and 6 species mechanisms as predicted whereas within themselves, they are consistent in terms of response speed. This can have a large impact on simulations unless the fluid flow time scales (whether diffusive or convective) is much larger than these values. The following definitions of flow time scales are considered:

Diffusive time scale:

$$
\tau_{d}=\frac{l^{2}}{v+v_{t}}
$$

Local convective time scale (cell residence time): 


$$
\tau_{c_{\text {local }}}=\frac{l}{|\mathbf{u}|}
$$

Global convective time scale:

$$
\tau_{c_{\text {global }}}=\frac{\text { flame length }}{\text { average velocity within flame }}
$$

The same point in the flow field thermodynamic state of which was sampled in step 1 of the described test procedure was used to calculate the following time scale values listed in Table 8.

\begin{tabular}{|c|c|c|}
\hline$\tau_{d}$ & $\tau_{c_{\text {local }}}$ & $\tau_{c_{\text {globa }}}$ \\
\hline$\sim 10^{-4}$ & $\sim 10^{-5}$ & $\sim 10^{-3}$ \\
\hline
\end{tabular}

Table 8 Fluid flow time scales in seconds.

Figure 10 reveals that even the overall slowest reaction mechanism reaches to the equilibrium state at around $10^{-6}$ seconds. Thus, at least for the near flame conditions, it can be assumed that the reactions reach a local equilibrium and the different mechanisms chosen here are expected to result in close, if not identical, solutions. In fact, Vaidyanathan et al. $^{23}$ injector case was solved with all the listed chemistry mechanisms and identical results were obtained. It should be noted that in the present computational framework, the chemical reaction is handled based on the "mean" flow variables, and no detailed treatment has been made in regard to turbulence-chemistry interactions. As is well known ${ }^{30}$, this aspect can substantially affect the outcome of the reaction rates and the mean thermal and velocity fields, hence it needs to be refined in the future.

\section{OH Number Density Comparison}

In terms of the wall heat flux, simulations show reasonable agreement with measurements (Figure 8). A more detailed look is given in Figure 11 by comparing near injector $\mathrm{OH}$ number densities. Simulation results in an order of magnitude greater $\mathrm{OH}$ number density compared to the measurement indicating an over prediction of the initial mixing rate. Reasons possibly rooted at the turbulence model and turbulence chemistry interaction are being investigated but no conclusions have been drawn yet.

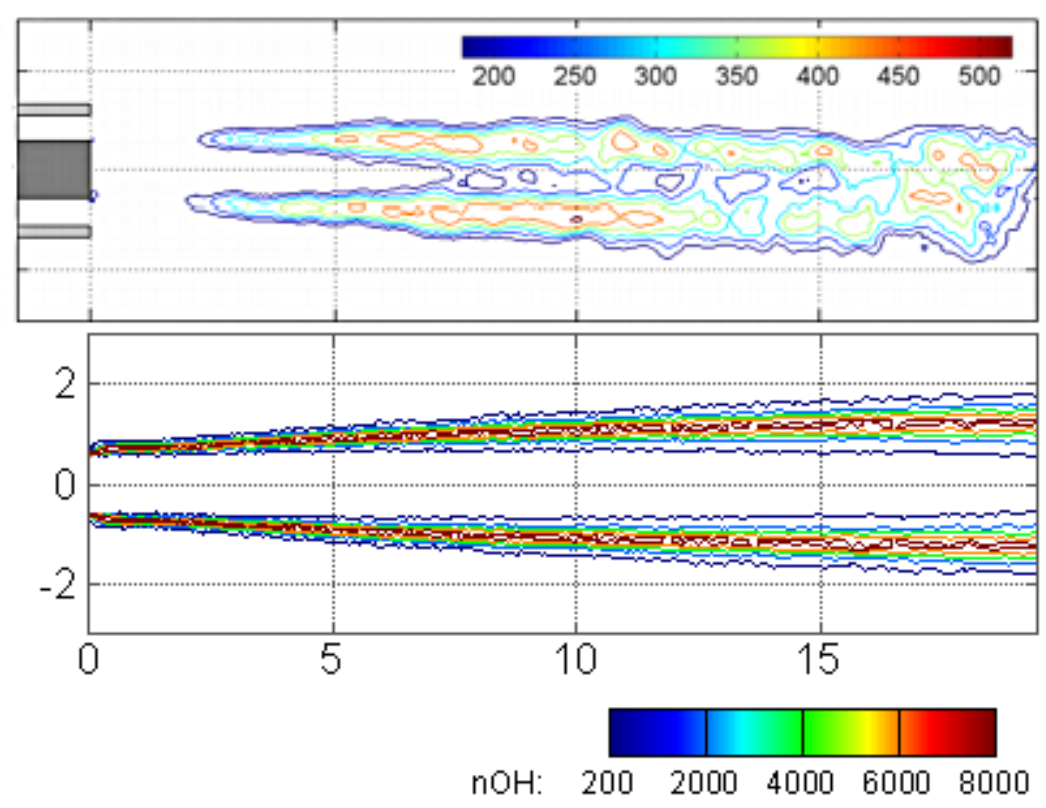

Figure 11 Number density of $\mathrm{OH}\left(10^{15}\right.$ molecules $\left./ \mathrm{cm}^{3}\right)$ (Vaidyanathan et al. ${ }^{23}$ injector), dimensions are in mm. Top: Experimental, Bottom: Current result for grid 3. 


\section{B. Pal et al. ${ }^{22}$ Injector}

This test case was studied before by Tucker et al. ${ }^{21}$ where several researchers simulated the same problem using a range of CFD methodologies and computational practices. A brief summary of methodologies is given in Table 9 and a comparison of wall heat flux values obtained in this study versus. Tucker et al. ${ }^{21}$ is provided later on in Figure 17.

Table 9 Computational modeling techniques adopted by Tucker et al. ${ }^{21}$ for Pal et al. ${ }^{22}$ experiment.

\begin{tabular}{cccccc}
\hline Designation & Chemistry & Turbulence Closure & Dimension & Grid Size & $\begin{array}{c}\text { Time Step } \\
(\boldsymbol{\mu s e c})\end{array}$ \\
\hline Tucker et al. ${ }^{21}-1$ & Finite-rate & LES & 3D & $255,000 \mathrm{~K}$ & 0.068 \\
Tucker et al. $.^{21}-2$ & Finite-rate & LES & 3D & $3,160 \mathrm{~K}$ & 0.01 \\
Tucker et al. $^{21}-3$ & Flamelet & LES & 2D & 263K & 0.1 \\
Tucker et al. ${ }^{21}-4$ & Finite-rate & URANS & 2D & 250K & 0.1 \\
Tucker et al. ${ }^{21}-5$ & Finite-rate & RANS & 2D & $400 \mathrm{~K}$ & 100 \\
\hline
\end{tabular}

We, instead, took a lateral approach, i.e., given our CFD framework of RANS turbulence closure and finite-rate chemistry, several aspects that may impact simulation accuracy are assessed. Our test matrix is summarized in Table 10. Baseline case options are shaded. For each following case, options are changed progressively. Two views of the grids 1 and 3 are given in Figure 12. Grid 2 is similar to grid 1 except that the latter has a more refined wall boundary layer so as to yield $y^{+}<1$. The geometry considered in the simulation is axisymmetric.

Table 10 Pal et al..$^{22}$ injector test cases.

\begin{tabular}{|c|c|c|c|c|c|c|}
\hline No & $\begin{array}{c}\text { Wall } \\
\text { Temperature }\end{array}$ & $\begin{array}{l}\text { Law-of- } \\
\text { the-wall? }\end{array}$ & $\begin{array}{l}\text { Chemistry } \\
\text { mechanism }\end{array}$ & Grid & $\begin{array}{c}\text { Number } \\
\text { of Cells }\end{array}$ & $\begin{array}{l}\mathbf{y}^{+} \text {max } \\
\text { at wall }\end{array}$ \\
\hline 1 & Fixed: $700 \mathrm{~K}$ & yes & $6 s 8 r$ & Grid 1 & $100 K$ & 15 \\
\hline 2 & $\begin{array}{c}\text { Experimental } \\
\text { Distribution }\end{array}$ & yes & $6 s 8 r$ & Grid 1 & $100 \mathrm{~K}$ & 13 \\
\hline 3 & $\begin{array}{c}\text { Experimental } \\
\text { Distribution }\end{array}$ & no & $6 s 8 r$ & Grid 2 & $127 \mathrm{~K}$ & 0.11 \\
\hline 4 & $\begin{array}{l}\text { Experimental } \\
\text { Distribution }\end{array}$ & no & $8 \mathrm{~s} 19 \mathrm{r}$ & Grid 2 & $127 \mathrm{~K}$ & 0.11 \\
\hline 5 & $\begin{array}{l}\text { Experimental } \\
\text { Distribution }\end{array}$ & no & $6 s 8 r$ & Grid 3 & $496 K$ & 0.24 \\
\hline
\end{tabular}

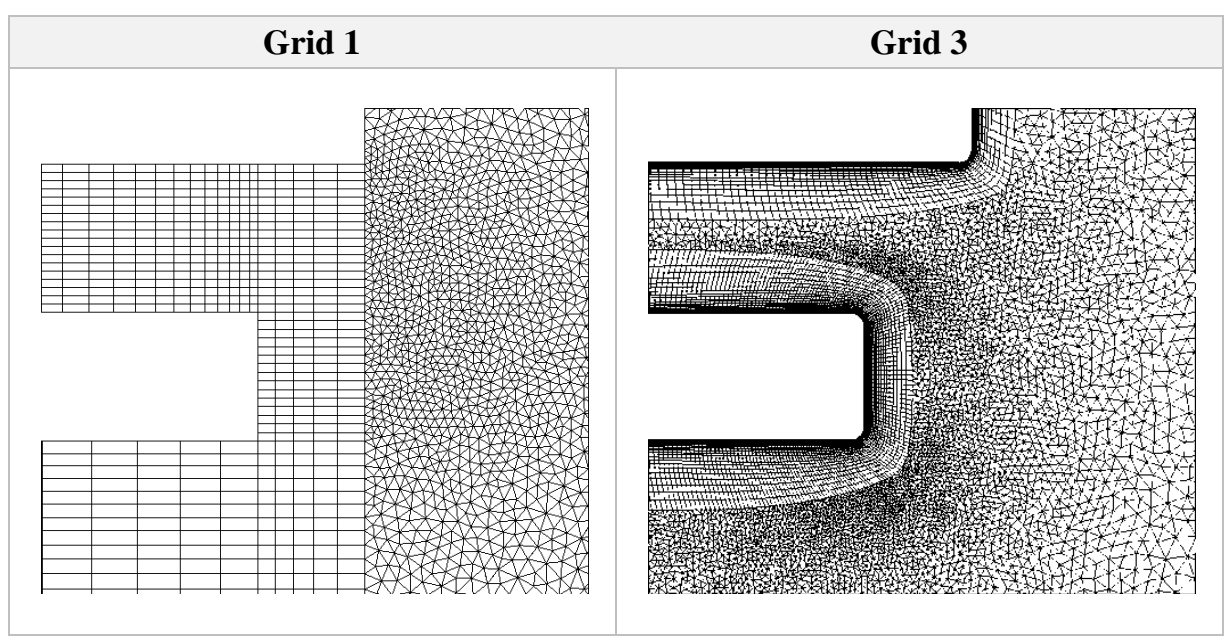



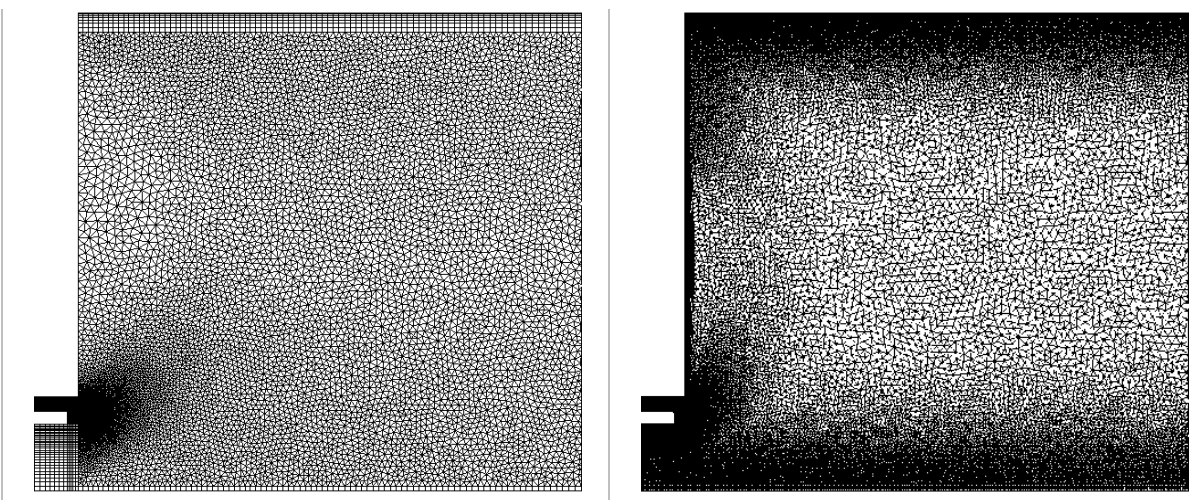

Figure 12 Grid views for Pal et al. ${ }^{22}$ injector. Top row: inlet close-up, Bottom row: Full height view of near inlet region.

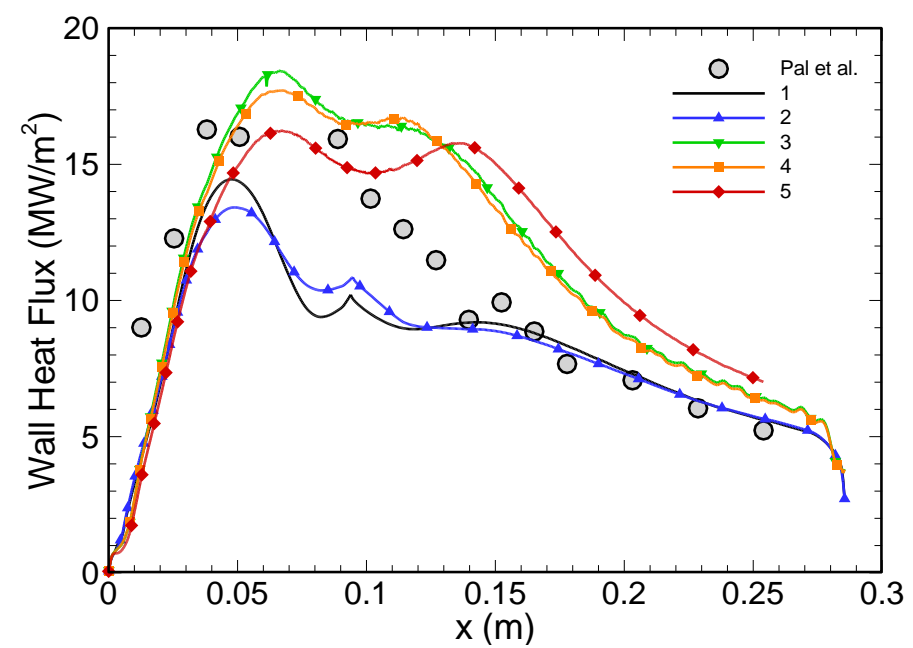

Figure 13 Wall heat flux distributions in comparison to experimental data by Pal et al. ${ }^{22}$.

Figure 13 shows wall heat flux distributions compared to the experimental measurements while Figure 14 and Figure 15 compares temperature and $\mathrm{OH}$ mass fraction fields for each case.

Case 1 vs. Case 2: Constant wall temperature of $700 \mathrm{~K} v$ s. imposing experimental temperature profile

Given a problem definition, a predictive CFD simulation should ideally be independent of incorporating any experimental measurement. For the current injector setup, this is a challenging objective in terms of the chamber wall thermal condition. In order to achieve independent simulations, one needs to perform a conjugate simulation of the solid enclosing the combustion chamber and the ambient flow which adds greatly to the complexity of the simulations. As an alternative, assigning an estimate constant wall temperature is explored and compared with the case of assigning the experimental temperature profile at the wall. The resulting temperature and $\mathrm{OH}$ mass fraction fields are indistinguishable. A slight difference in wall heat flux distributions is observed while the integrated wall heat transfer values were similar.

Case 2 vs. Case 3: Using the law of the wall vs. integrating to the wall

The law of the wall treatment is based on an assumed velocity profile and an analogy between shear stress and heat flux. The assumed near wall velocity profile is based on a non-recirculating wall-bounded flow structure. Its applicability to complex flow fields involving substantial flow curvatures, recirculation, and pressure gradients is limited. The direct integration to the wall is conceptually more appropriate to resolve the small length scale phenomena such as shear stress and heat flux. A competing issue is that the wall dampens the turbulent fluctuation and the Reynolds number locally, requiring that the turbulence closure be revised. This requires a good handling of the local flow structures and is not a straightforward task. Our focus here is to conduct computational assessment of the alternative wall treatments to help shed light on the effectiveness and the challenge of them.

Integrating to the wall, in this case, resulted in a better prediction of the peak wall heat flux value whereas use of the law of the wall yielded a corresponding under prediction. Note that the recirculating region extends up to 
$x \approx 0.1 \mathrm{~m}$. Further downstream after the re-attachment point, a reversal of the trend is observed consistent with the argument above; law of the wall result more closely follows the experimental data and integrating to the wall causes an over-prediction there. Figure 16 shows axial velocity and temperature profiles along the chamber section at $1 / 4^{\text {th }}$ and $3 / 4^{\text {th }}$ chamber lengths corresponding to recirculating and attached flow regions respectively. Integrating to the wall consistently results in effectively fuller momentum and thermal boundary layers, hence a larger shear stress and heat transfer rate. Increased heat loss causes an overall cooler thermal field and a decreased extent of the flame as observed in Figure 14 and Figure 15.

Case 3 vs. Case 4: 6 species 8 reactions chemistry mechanism vs. 8 species 19 reactions mechanism.

For the previous injector setup based on Vaidyanathan et al. ${ }^{23}, 4$ different chemistry mechanisms were tested and found to yield identical results. For the Pal et al. ${ }^{22}$ injector, however, we observe a minimal overall decrease in wall heat flux and a slight increase in $\mathrm{OH}$ mass fraction near the flame core. The underlying reasons need to be investigated to be able to offer more insight.

Case 4 vs. Case 5: Grid refinement

Grid 3 used for case 6 is substantially finer near the injector post, flame core and chamber wall boundary. An outcome similar to the grid independence study of the Vaidyanathan et al. ${ }^{23}$ injector is reached: Refined grid causes a slower mixing of fuel and oxidizer streams, hence increasing the flame length as can be seen from Figure 14 and Figure 15. Shifting of the flame towards downstream also reflects on the wall heat flux profile with elevated values downstream and a reduced peak value.

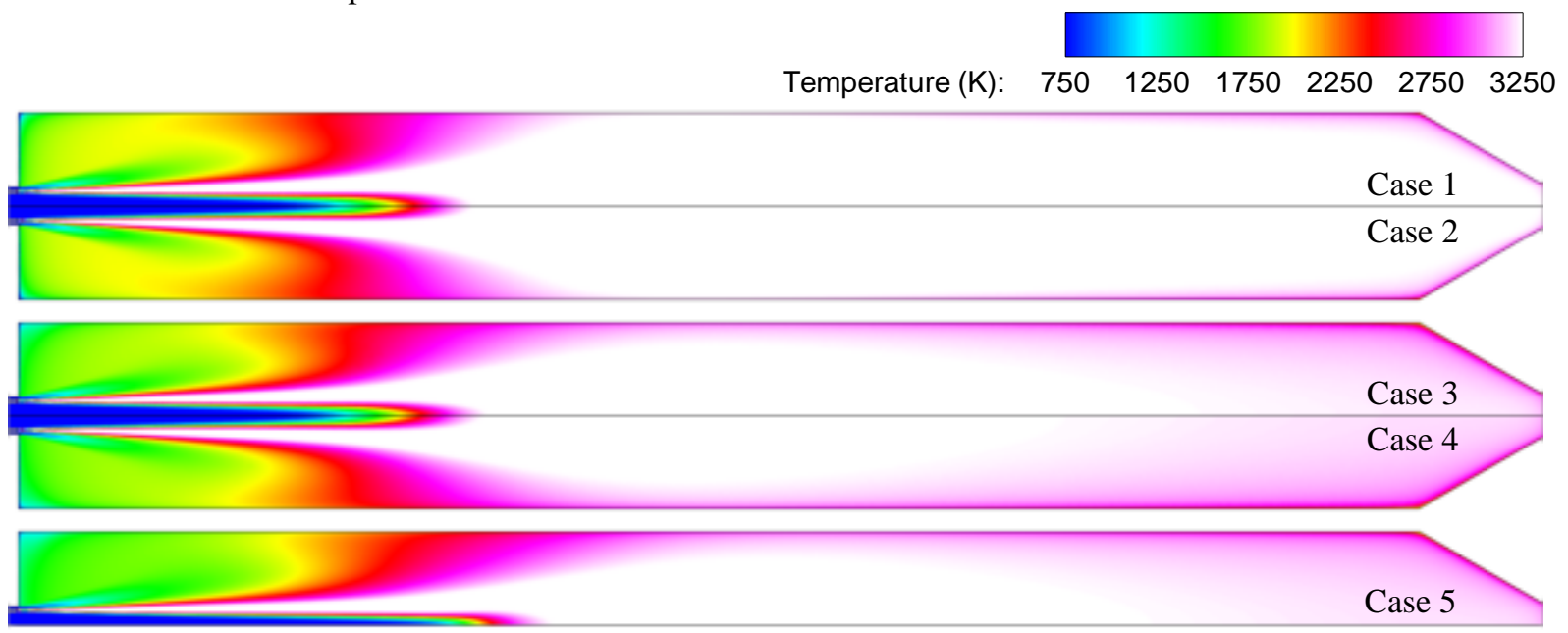

Figure 14 Comparative views of the temperature fields (Pal et al..$^{22}$ injector).

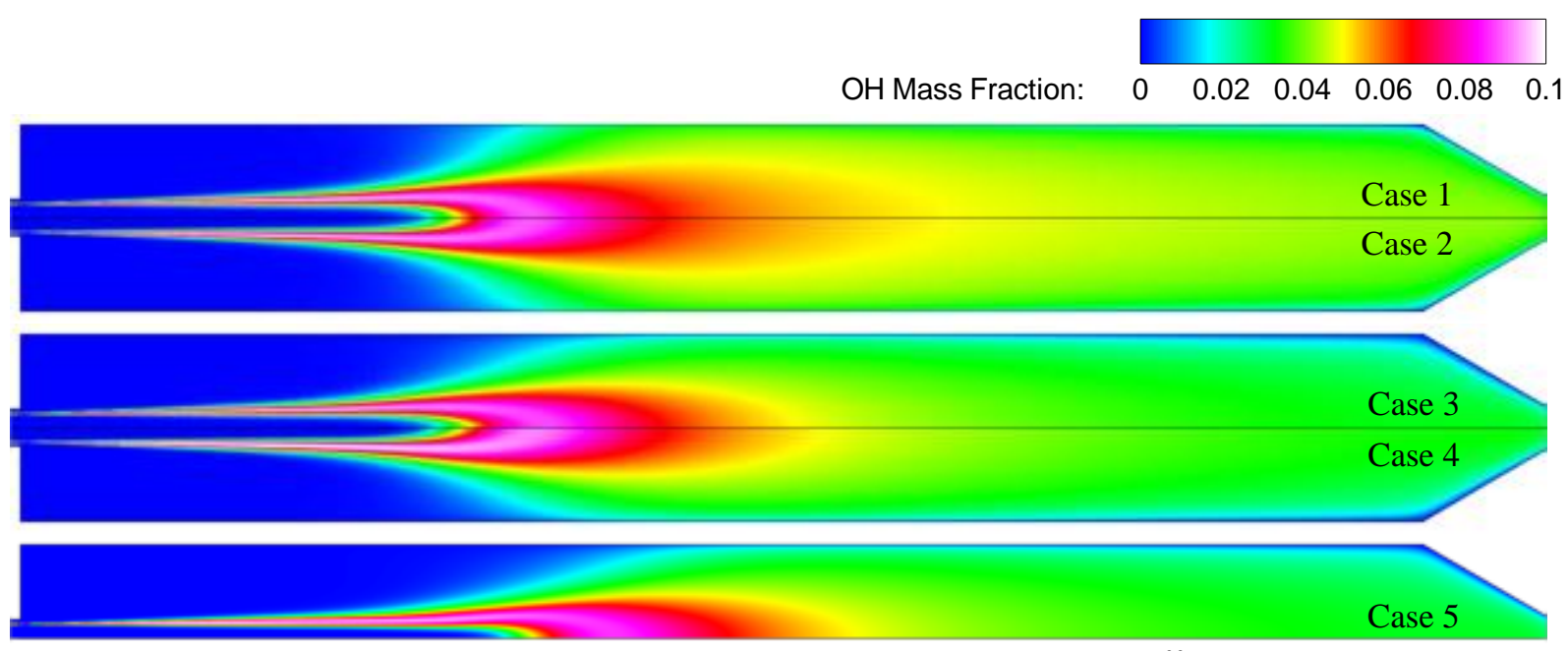

Figure 15 Comparative views of $\mathrm{OH}$ mass fraction fields (Pal et al. ${ }^{22}$ injector). 


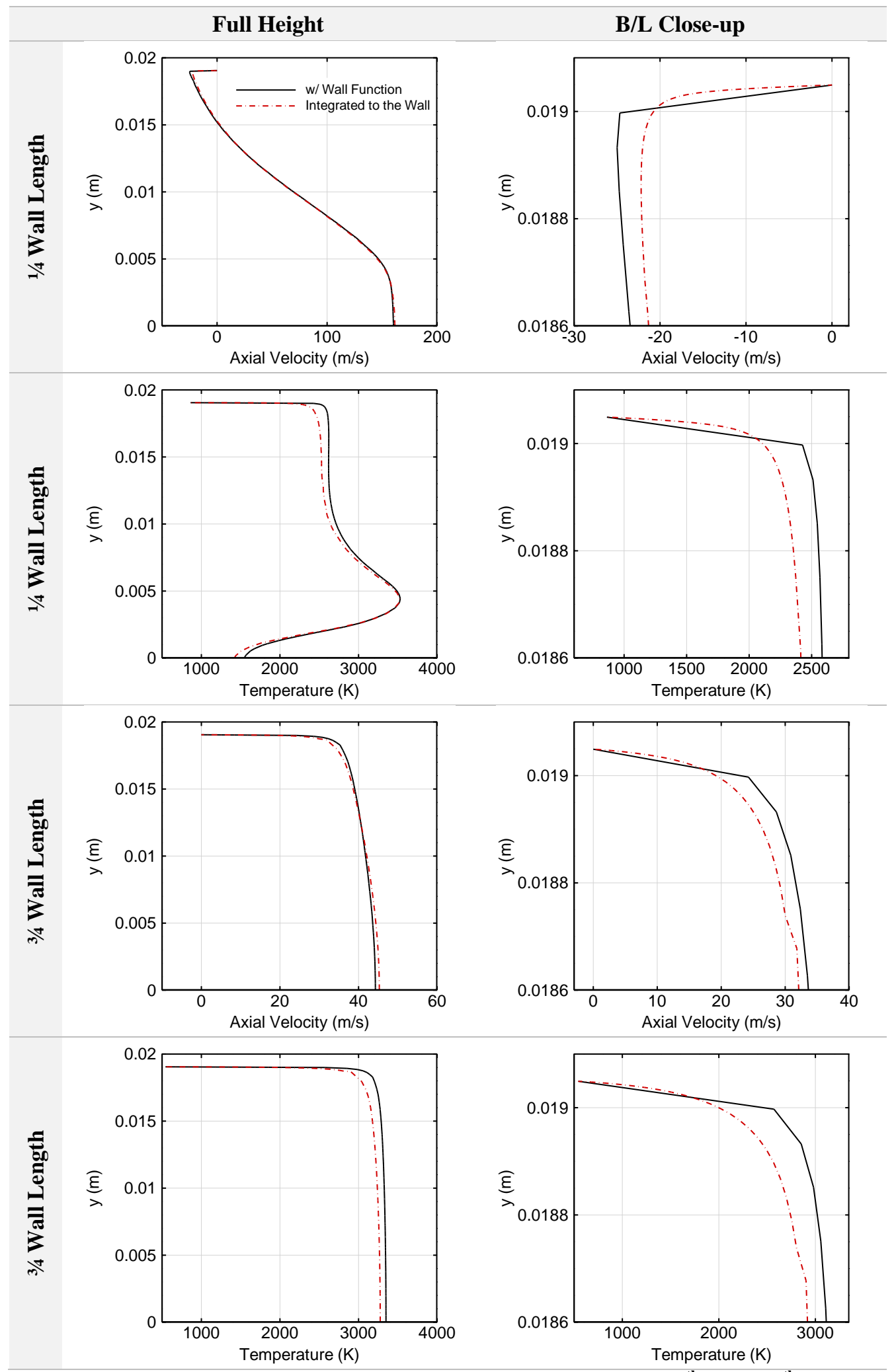

Figure 16 Axial velocity and temperature profiles along chamber height at $1 / 4^{\text {th }}$ and $3 / 4^{\text {th }}$ chamber length sections (Pal et al. ${ }^{22}$ injector). 
Case 6 vs.Tucker et al ${ }^{21}$

Figure 17 shows our current wall heat flux results in comparison to those reported by Tucker et al. ${ }^{21}$. The first observation, also noted by Tucker et al. ${ }^{21}$, is that there is no progressive convergence to experimental results as the CFD model fidelity is increased. However the Tucker et al. ${ }^{21}-1$ case, which uses LES together with a 255 million cell grid, exhibits the overall best match to the experimental data. Our RANS model results, depending on whether the law-of-the-wall was used or not, display partial close match to experimental profile in either the downstream or upstream portion of the wall respectively. A logical next step for us here is to adopt integrating to wall for the upstream recirculating region but to switch to the law-of-the-wall treatment in the downstream portion following the reattachment point. Current results suggest that the RANS framework can be an accurate and relatively feasible tool for predicting injector type flows.

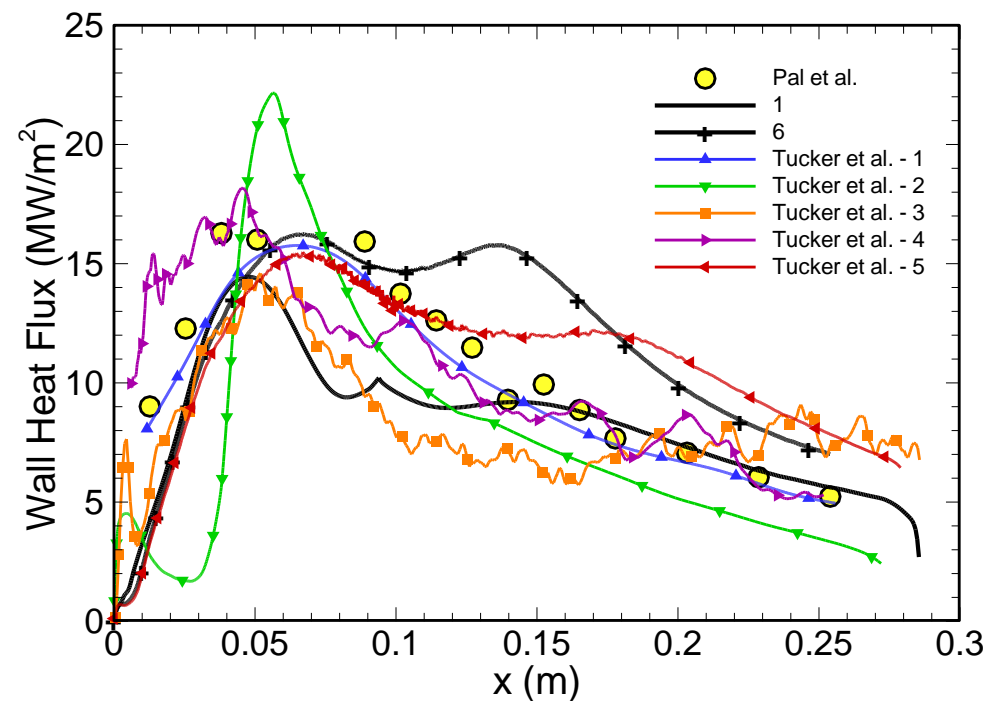

Figure 17 Comparison of current chamber wall heat flux results and those of Tucker et al. ${ }^{21}$.

\section{Summary and Conclusions}

Two different experimental $\mathrm{GO}_{2} / \mathrm{GH}_{2}$ single element shear coaxial injectors due to Vaidyanathan et al. ${ }^{23}$ and $\mathrm{Pal}$ et al. $^{22}$ were modeled and tested with a CFD framework based on RANS turbulence closure and finite rate chemistry. Impacts of grid refinement, different choices of chemistry mechanisms and near wall treatments were assessed.

In both test cases, grid refinement resulted in a reduced mixing rate and hence a downstream shift of the flame. Effect of the refinement on wall heat flux profiles were less pronounced. Vaidyanathan et al. ${ }^{23}$ injector was more extensively tested for this aspect with 5 different grid resolutions and convergence to a grid insensitive level was demonstrated.

Four different chemistry mechanisms were selected and tested for Vaidyanathan et al. ${ }^{23}$ injector whereas two of them were evaluated for Pal et al. ${ }^{22}$ injector. The simulation results were identical for the former injector whereas a minimal difference is observed for the latter one. Time scales of each reaction mechanisms were investigated in an analysis of introducing additional $\mathrm{O}_{2}$ to an equilibrium condition and examining the time history of their response. It was noted that with a detailed treatment of turbulence-chemistry interaction, choice of the chemistry mechanism can make a larger impact on the outcome ${ }^{30}$.

Pal et al. ${ }^{22}$ injector case was also tested for different choices of combustion chamber wall temperature boundary conditions and near wall treatment of turbulence.

Imposing a constant value of wall temperature versus using the experimentally measured temperature distribution didn't cause a noticeable effect in flow field. Wall heat flux distribution was slightly affected but in an integral sense, total heat transfer to the wall was unchanged.

Use of the law-of-the-wall versus integrating to the wall with a refined wall boundary layer grid distribution by far caused the largest difference in our tests. Advantages and shortcomings of each approach were discussed. Former approach was shown to yield a better agreement with experimental wall heat flux distribution where the flow is attached to the wall. In recirculation region, however, the latter approach performed better. A blend of the two based on flow attachment to the wall is worth further exploring. 
Wall heat flux results for Pal et al. ${ }^{22}$ injector case were compared to those of Tucker et al. ${ }^{21}$ who employed various CFD methodologies to simulate the same problem. The current RANS methodology provided comparable results to those reported by Tucker et al. ${ }^{21}$ (except for the case with very large number of grid points using LES, which shows consistently better agreement than other studies). However, the scatter between the various efforts is substantial. Clearly, there is room for improvement in terms of the turbulence-chemistry interaction as well as the wall treatment discussed above.

\section{Acknowledgments}

This study is supported by the NASA Constellation University Institute Program (CUIP), Claudia Meyer and Jeff Rybak program managers. We have benefited from collaboration with Dr. Edward A. Luke of Mississippi State University and Mr. Kevin Tucker of NASA Marshall Space Flight Center.

\section{References}

${ }^{1}$ Foust, M.J., Deshpande, M., Pal, S., Ni, T., Merkle, C.L., Santoro, R.J., "Experimental and analytical characterization of a shear coaxial combusting $\mathrm{GO}_{2} / \mathrm{GH}_{2}$ flowfield," AIAA-96-0646, 34th AIAA Aerospace Sciences Meeting and Exhibit, Jan 15-18, Reno, NV, 1996

${ }^{2}$ Venkateswaran, S., Weiss, J.M., Merkle, C.L., Choi, Y.-H., "Propulsion-related flowfields using the preconditioned NavierStokes equations," AIAA Paper 92-3437 , 28 th AIAA/ASME/SAE/ASEE Joint Propulsion Conference and Exhibit, Nashville, TN, July, 1992.

${ }^{3}$ Schley, C.-A., Hagemann, G., Tucker, K.P., Venkateswaran, S., Merkle, C.L., "Comparison of computational codes for modeling hydrogen-oxygen injectors," AIAA-1997-3302, 33 ${ }^{\text {rd }}$ AIAA/ASME/SAE/ASEE Joint Propulsion Conference and Exhibit, Seattle, WA, July, 6-9, 1997.

${ }^{4}$ Schley, C.-A., Hagemann, G., Golovitchev, V., "Comparison of high pressure H2/O2 rocket model engine reference simulations," AIAA-95-2429, $31^{\text {st }}$ AIAA/ASME/SAE/ASEE Joint Propulsion Conference and Exhibit, Monterey, CA, June 28-30, 1995.

${ }^{5}$ Chen, Y.S., "Compressible and incompressible flow computations with a pressure based method," AIAA Paper 89-0286, 27 th AIAA Aerospace Sciences Meeting and Exhibit, Reno, NV, Jan. 1989.

${ }^{6}$ Oefelein, J.C., Yang, V., "Modeling high-pressure mixing and combustion processes in liquid rocket engines," Journal of Propulsion and Power, vol. 14, no. 5, 1998.

${ }^{7}$ Mayer, W., Tamura, H., "Propellant injection in a liquid oxygen/gaseous hydrogen rocket engine," Journal of Propulsion and Power, vol. 12, pp. 1137-1147, 1996.

${ }^{8}$ Ivancic, B., Mayer, W., "Time- and length scales of combustion in liquid rocket thrust chambers," Journal of Propulsion and Power, vol. 18, no. 2, 2002.

${ }^{9}$ Lin, J., West, J.S., Williams, R.W., Tucker, K.P., "CFD code validation of wall heat fluxes for a $\mathrm{GO}_{2} / \mathrm{GH}_{2}$ single element combustor," AIAA-2005-4524, 41 ${ }^{\text {st }}$ AIAA/ASME/SAE/ASEE Joint Propulsion Conference and Exhibit, Tucson, AZ, July, 10-13, 2005 .

10 Marshall, W.M., Pal, S., Woodward, R.D., Santoro, R.J., "Benchmark wall heat flux data for a $\mathrm{GO}_{2} / \mathrm{GH}_{2}$ single element combustor," AIAA-2005-3572, 41 ${ }^{\text {st }}$ AIAA/ASME/SAE/ASEE Joint Propulsion Conference and Exhibit, Tucson, AZ, July, 10-13, 2005 .

11 Luke, E.A. and George, T., "Loci : A rule-based framework for parallel multidisciplinary simulation synthesis," Journal of Functional Programming, vol. 15, no. 3, 477-502, May 2005.

12 Luke, E. and Cinnella, P., "Numerical simulations of mixtures of fluids using upwind algorithms," Computers \& Fluids, vol. 36, no. 10, 1547-1566, doi:10.1016/j.compuid.207.03.008, 2007.

13 Oefelein, J.C., "Numerical mixing and combustion of cryogenic oxygen-hydrogen shear-coaxial jet flames at supercritical pressure," Combust. Sci. and Tech., 178:229-252, 2006.

14 Oschwald, M., Smith, J.J., Branam, R., Hussong, J., Schik, A., "Injection of fluids into supercritical environments," Combust. Sci. and Tech., 177:2087-2138, 2005.

15 Cheng, G.C., Farmer, R., "Real fluid modeling of multiphase flows in liquid rocket engine combustors," Journal of Propulsion and Power, vol. 22, no. 6, 2006

16 Vingert, L., Habiballah, M., "Test case RCM 2: cryogenic spray combustion at 10 bar at Mascotte," Proceedings of the 2nd International Workshop on Rocket Combustion Modeling, Deutsches Zentrum fur Luft-und Raumfahrt (DLR), Lampoldshausen, Germany, 2001

17 Thomas, J.L., Zurbach, S., "Test case RCM 3:supercritical spray combustion at 60 bar at Mascotte," Proceedings of the 2nd International Workshop on Rocket Combustion Modeling, Deutsches Zentrum fur Luft-und Raumfahrt (DLR), Lampoldshausen, Germany, 2001

18 Mack, Y., Haftka, R., Segal, C., Queipo, N., Shyy, W., "Computational modeling and sensitivity evaluation of liquid rocket injector flow," AIAA-2007-5592, 43 ${ }^{\text {rd }}$ AIAA/ASME/SAE/ASEE Joint Propulsion Conference and Exhibit, Cincinnati, OH, July, 8-11, 2007. 
19 Conley, A., Vaidyanathan, A., Segal, C., "Heat flux measurements in a GH2/GO2 single-element injector," AIAA-20065048, 42 ${ }^{\text {nd }}$ AIAA/ASME/SAE/ASEE Joint Propulsion Conference and Exhibit, Sacramento, CA, July, 9-12, 2006.

20 Thakur, S. and Wright, J., "Validation of a pressure-based combustion simulation tool for a single element injector test problem," 3rd International Workshop on Rocket Combustion Modeling, Paris, France, March 13-15, 2006.

21 Tucker, P.K, Menon, S., Merkle, C.L., Oefelein, J.C., Yang, V., "Validation of high-fidelity CFD simulations for rocket injector design," AIAA-2008-5226, $44^{\text {th }}$ AIAA/ASME/SAE/ASEE Joint Propulsion Conference and Exhibit, Hartfrod, CT, July, 21-23, 2008.

22 Pal, S., Marshall, W., Woodward, R., Santoro, R., "Wall heat flux measurements for a uni-element $\mathrm{GO}_{2} / \mathrm{GH}_{2} \mathrm{shear} \mathrm{coaxial}$ injector," Third International Workshop on Rocket Combustion Modeling, Paris, France, March, 13-15, 2006.

${ }_{23}$ Vaidyanathan, A., Gustavson, J., Segal, C. "Heat fluxes/OH PLIF measurements in a $\mathrm{GO}_{2} / \mathrm{GH}_{2}$ single-element, shear injector," AIAA-2007-5591, 43 ${ }^{\text {rd }}$ AIAA/ASME/SAE/ASEE Joint Propulsion Conference and Exhibit, Cincinnati, OH, July, 8-11, 2007.

24 Roe, P.L., "Approximate Riemann solvers parameter vectors and difference schemes,” J. Comp. Phys., 43, 357-372, 1981.

25 Menter, F.R., "Zonal two equation k- $\omega$ turbulence models for a erodynamic flows," AIAA Paper 93-2906, 1993.

26 Launder, B. E. and Spalding, D. B., "The numerical computation of turbulent flows," Computer Methods in Applied Mechanics and Engineering, 3(2): 269-289, 1974

27 Evans, J.S., Schexnayder, C.J., "Influence and chemical kinetics and unmixedness on burning in supersonic hydrogen flames," AIAA Journal, vol. 18, no. 2, pp. 188-193, 1980.

28 Gontkovskaya, V.T., Gordopolova, I.S., Ozerkovskaya, N.I., "Hydrogen oxidation at non-isothermal conditions," J. Phys. Combust. Explosions, vol. 28, no. 1, 1988.

29 Ó Conaire, M., Curran, H.J., Simmie, J.M., Pitz, W.J., Westbrook, C.K., "A comprehensive modeling study of hydrogen oxidation," International Journal of Chemical Kinetics, vol. 36, pp. 603-622, 2004.

30 Correa, S. M., Shyy, W., "Computational models and methods for continuous gaseous turbulent combustion," Progress in Energy and Combustion Science, vol. 13, pp. 249-292, 1987. 